\title{
A INICIATIVA POPULAR NO SISTEMA CONSTITUCIONAL BRASILEIRO: FUNDAMENTOS TEÓRICOS, CONFIGURAÇÃO E PROPOSTAS DE MUDANÇAS ${ }^{1}$
}

\section{POPULAR INITIATIVE IN BRAZILIAN CONSTITUTIONAL SYSTEM: THEORICAL BACKGROUND, CONFIGURATION AND PROPOSALS FOR CHANGE}

\author{
Jane Reis Gonçalves Pereira²
}

\begin{abstract}
A iniciativa popular desmistifica a representação em sentido liberal e força o parlamentar a sair de sua pele. Ela quebra pelo menos o teor imobilista $e$ ritual de um entendimento enviesado do mandato, que confere ao parlamentar a facilidade de confundir a sua voz e o seu querer, com a voz do povo e os interesses dos representados, em regra esquecidos "até as próximas eleições".

Florestan Fernandes (1987)
\end{abstract}

\section{Resumo}

O presente estudo examina o instituto da iniciativa popular no ordenamento jurídico brasileiro. $\mathrm{Na}$ primeira parte, é tratada a divisão entre representação e participação, confrontando o surgimento da democracia semidireta (e da iniciativa popular) com as correntes democráticas modernas e contemporâneas. Na segunda, é analisada a configuração do instituto no sistema jurídico brasileiro, propondo alterações que permitam incentivar e facilitar o seu uso no processo político.

Palavras-Chave: Iniciativa popular; democracia semidireta; democracia representativa; democracia deliberativa; democracia participativa.

\begin{abstract}
The current study examines the institute of popular initiative in the Brazilian legal system. In the first part, the division between representation and participation is treated, confronting the emergence of semi-direct democracy (and popular initiative) with modern and contemporary democratic currents. Second, it analyzes the configuration of the institute in the Brazilian legal system, proposing changes to allow encourage and facilitate its use in the political process.
\end{abstract}

Keywords: Popular initiative; semidirect democracy; representative democracy; deliberative democracy; participative democracy.

\footnotetext{
${ }^{1}$ Agradeço imensamente a ajuda inestimável prestada por Renan Medeiros de Oliveira na pesquisa e edição deste artigo.

${ }^{2}$ Doutora em Direito Público pela UERJ. Professora Adjunta de Direito Constitucional da UERJ. E-mail: janergp@gmail.com
} 


\section{INTRODUÇÃO}

A afirmativa de que o processo democrático não se esgota nas eleições é corriqueira no discurso político. As discussões sobre as ferramentas de participação direta sempre mobilizaram os teóricos da democracia, embora ocupando espaço menor do que os problemas relativos à representação. No plano da realidade, porém, o exercício do poder se opera preponderantemente por meio de instituições efetiva ou virtualmente representativas.

Os valores fundamentais do constitucionalismo liberal geraram demandas de participação como forma de legitimação do poder político. A partir dos sucessivos embates sobre os meios de formulação da vontade estatal, cindiu-se a participação dos cidadãos em três níveis: participação direta, eleitoral e representativa ${ }^{3}$, apresentando-se a díade participação direta/representação, ao menos num primeiro momento, como versões incompatíveis do exercício democrático. Nesse contexto, o constitucionalismo liberal, em seu nascedouro, prestigiou as instituições representativas.

Os mecanismos de participação direta na vida política, todavia, muito cedo foram acatados pelas constituições democráticas, ainda que de forma restrita e eventual. Após a primeira Guerra Mundial esses institutos adquiriram maior importância. Aguiar de Luque, examinando a experiência europeia ainda na década de setenta, afirmava não parecer exagerado dizer que as ferramentas de democracia semidireta constituem uma das características mais significativas do constitucionalismo recente (LUQUE, 1977, p. 10).

Ainda assim, há quem encare os mecanismos que propiciam a participação imediata dos cidadãos no processo político como algo anacrônico e politicamente inexecutável no contexto da sociedade contemporânea, considerando as limitações de tempo e interesse dos cidadãos em participar da vida cívica. Paralelamente, há quem os veja como persistentes ameaças aos pilares do estado liberal, por entenderem que encerram o risco de subverter a autonomia individual a partir de uma imposição autoritária da vontade da maioria ${ }^{4}$.

Não obstante, os instrumentos de participação direta no processo legislativo estão hoje previstos em grande parte das constituições democráticas, e são utilizados com razoável eficácia em vários dos sistemas que os consagram, muitas vezes atuando como corretivos à democracia representativa tradicional. De fato, o binômio representação/participação não contém duas categorias necessariamente antinômicas, mas possível e desejavelmente complementares. Para

\footnotetext{
${ }^{3}$ Terminologia de De Esteban, citado por LUQUE, 1977.

${ }^{4}$ Vejam-se, por exemplo, CHEMERINSKY, 2007 e CLARK, 1998.
} 
além dessa dicotomia, a participação direta, combinada com balizas constitucionais que estabeleçam a proteção dos direitos individuais e de minorias, pode funcionar como ativadora da deliberação política, conectando vantagens da democracia participativa, da democracia representativa e da democracia deliberativa.

No Brasil, o advento da Constituição de 1988 promoveu uma alteração radical na fórmula da soberania, ao prever, em seu artigo 10 que "todo poder emana do povo, que o exerce por meio de representantes eleitos ou diretamente". Como desdobramento lógico do termo "diretamente", previu o texto constitucional o plebiscito, o referendo e a iniciativa popular, que constitui o objeto deste artigo. A iniciativa popular é um instrumento mediador de participação, pois, diferentemente do plebiscito e do referendo, não viabiliza a imposição de uma decisão estatal definitiva pela manifestação de vontade da maioria numérica. Esse instrumento pode funcionar como um duto de conexão entre movimentos sociais e o poder legislativo, atenuando os déficits de representação política e fomentando a deliberação democrática.

A iniciativa popular legislativa tem potencial para funcionar como uma das mais dinâmicas ferramentas de participação direta, tendo em vista duas características que a distinguem. De um lado, seu caráter predominantemente ativo e de "baixo para cima", já que corresponde à formulação de uma proposta, e não de uma mera resposta aos governantes, o que a torna apta a funcionar como um canal de vocalização de demandas que surjam espontaneamente no seio da sociedade civil. De outro, o fato de estabelecer um canal formal permanente de integração entre a sociedade civil organizada e as instituições estatais, porquanto as proposições populares podem deflagrar a atuação das instâncias tradicionais de representação política, que têm a chance de acatar, redesenhar ou formular proposições alternativas às apresentadas, mediando a conversão das demandas sociais em decisões estatais definitivas. As iniciativas populares, diferentemente dos plebiscitos e referendos, não precisam ser ativadas apenas para a deliberação de assuntos excepcionais ou com alta carga de divergência política. Ao contrário, podem funcionar como fórmula corriqueira de acionamento do processo legislativo, despertando a atenção do Estado para temas que influenciam o cotidiano das pessoas e ficam fora do radar das instituições formais. Por outro lado, a depender de sua configuração, elas não precisam envolver custos tão elevados quanto os necessários para a mobilização da máquina eleitoral usada em plebiscitos e referendos.

O tema não recebe muita atenção da doutrina nacional, especialmente na área jurídica 5 .

\footnotetext{
${ }^{5}$ Os manuais de direito constitucional, geralmente, não consagram mais do que algumas linhas a seu estudo, e mesmo os demais institutos de democracia semidireta recebem tratamento lacônico. Por outro lado, a
} 
Uma explicação para esse desinteresse é o fato de a aplicação do instituto no Brasil ser extremamente limitada, cabendo destacar que os dispositivos da Constituição de 1988 sobre o tema só foram regulados dez anos depois, com o advento da Lei 9.709, de 18 de novembro de 1998. Esse diploma legal, entretanto, ficou muito aquém das expectativas daqueles que discutiram a questão da participação no processo legislativo ${ }^{6}$, deixando de suprir lacunas importantes, especialmente quanto à regulação da iniciativa popular, à qual dedica apenas dois artigos.

O presente estudo encontra-se dividido em duas partes. Na primeira, me ocupo da divisão entre representação e participação, procurando situar o surgimento da democracia semidireta (e da iniciativa popular) com as correntes democráticas modernas e contemporâneas. Na segunda, examino a configuração do instituto no sistema jurídico brasileiro, propondo alterações que permitam incentivar e facilitar o seu uso no processo político. Por fim, exploro os argumentos em favor da tese de que essa ferramenta é apta a promover uma conciliação entre elementos da democracia participativa, da representativa e da deliberativa, o que justifica o esforço de facilitar seu uso na política cotidiana.

\section{DEMOCRACIA DIRETA, INDIRETA E SEMIDIRETA. REPENSANDO O BINÔMIO PARTICIPAÇÃO/REPRESENTAÇÃO}

A democracia, mais do que um modelo de governo, é hoje um valor absorvido em todo o mundo ocidental. Com efeito, não é exagero dizer que a maioria das constituições contemporâneas busca estabelecer, em seus textos, sistemas democráticos.

Definir a democracia parece, em uma primeira tentativa, extremamente simples. Recorrese com frequência à célebre síntese de Lincoln: "governo do povo, pelo povo e para o povo" 7 . Essa fórmula, entretanto, é insuficiente para responder à questão sobre o verdadeiro alcance da democracia, tendo em vista os múltiplos significados que adquiriu o termo no contexto político

bibliografia específica existente sobre o tema também é escassa. No âmbito da ciência política destacam-se dois trabalhos, os quais abordam a iniciativa popular, o referendo e o plebiscito simultaneamente. O primeiro, mais profundo, elaborado por Maria Victoria Benevides (1996), e o segundo, de José Álvaro Moisés (1990). No âmbito do direito, v. os trabalhos de Humberto Laport de Mello (2013) e de Adrian Sgarbi (1999). ${ }^{6}$ Cfr. BENEVIDES, 1996.

${ }^{7}$ Como averba Giovanni Sartori (1994) “democracia é uma palavra transparente, isto é, uma palavra simples de ancorar num significado literal, original. Por isso é facílimo definir democracia verbalmente. Em termos literais, democracia significa "poder do povo", significa que o poder pertence ao povo. Mas isso não passa de uma definição ao pé da letra, que traduz para uma língua conhecida o significado grego do termo. " Por outro lado, é verdade que, mesmo a fórmula de Lincoln, como assinala Sartori, não permite uma análise exata, já que, dissecados seus elementos, podem-se extrair diversas fórmulas políticas. Assim, "frase de Lincoln define democracia exatamente por ter sido pronunciada por Lincoln.". 
contemporâneo.

Sobre a imprecisão do conceito de democracia, Giovanni Sartori (1994) lembra a amarga conclusão de Bertrand de Jouvenel, que no ano de 1945, afirmou: "as discussões sobre democracia, os argumentos contra ela e a seu favor, não têm valor intelectual, porque não sabemos do que estamos falando". E comenta: "Até os anos 40, as pessoas sabiam o que era democracia e gostavam dela ou a rejeitavam; depois disso, todos nós dizemos gostar da democracia, mas não sabemos mais (não entendemos mais, não há concordância sobre) o que ela é. Vivemos, portanto, caracteristicamente, numa era de democracia confusa.".

Não há dúvida de que o termo adquiriu uma miríade de significados em decorrência, principalmente, do fato de que, a partir da segunda metade do século passado, não houve teorias ordenadas que pretendessem defender a legitimidade política dos regimes políticos realçando seu caráter antidemocrático. Assim, procura-se adequar o conceito de democracia aos contextos mais diversos, convertendo-a em um ideal regulativo que abarca fórmulas e ideias muito distintas entre $\mathrm{si}^{8}$. No entanto, o fato de a democracia apresentar-se como um conceito essencialmente contestado $^{9}$ não impede de identificar alguns de seus contornos. Em linhas mínimas, pode-se afirmar que a democracia pressupõe um liame entre a vontade do povo - definido mediante critérios objetivos e igualitários para o exercício da cidadania - e a formação da vontade política, por meio de instituições que viabilizam a eleição e o controle periódico dos que governam, com respeito às minorias e à liberdade de expressão. Essa definição rudimentar não acomoda os muitos significados e as múltiplas classificações de democracia ligadas a aspectos históricos, econômicos, políticos e institucionais. Na sofisticada teoria política contemporânea, convivem diversas correntes descritivas e normativas sobre a democracia. Abordarei aqui apenas as três tradições que guardam relação com a dicotomia representação versus participação - a democracia direta, a democracia indireta e a semidireta ${ }^{10}$-, relacionando-as às principais correntes teóricas contemporâneas que lastrearam seu surgimento e as que fundamentam a discussão contemporânea.

\footnotetext{
${ }^{8}$ A propósito, Robert Dahl (1992, cap. 3), afirmando que a vulgarização do termo democracia teria acarretado seu esvaziamento, sugere que seja mantida como um ideal, mas adota a palavra poliarquia para descrever os sistemas contemporâneos.

${ }^{9} \mathrm{~A}$ ideia de que a democracia consistiria num conceito essencialmente contestado busca demonstrar que se trata de um conceito sujeito a inúmeras disputas e divergências de pensamento, que podem ser sustentados por argumentos coerentes. A noção ficou conhecida desde o trabalho do filósofo Walter Gallie (1955-1956). Sobre o tema, v., ainda, os trabalhos de Michael Freeden (1998) e William Connolly (1993).

${ }^{10}$ Para um tratamento sistemático das grandes tradições democráticas (direta, indireta e semidireta) veja-se Bobbio (1995d), verbete "Democracia".
} 


\section{DEMOCRACIA DIRETA: A EXPERIÊNCIA GREGA, O PENSAMENTO DE ROUSSEAU E A TEORIA DE DEMOCRACIA PARTICIPATIVA.}

Ao falar-se em participação política, não é incomum começar com referências ao modelo de democracia ateniense. A participação política dos antigos representa historicamente o primeiro modelo de democracia, aquele conceituado como democracia direta. Porém, este modelo não foi o mesmo durante toda a antiguidade. Na Grécia, assim como em Roma, a democracia foi fruto de revoluções decorrentes de lutas de classes, que deram origem à república democrática grega e à romana.

A principal referência à experiência de participação política direta na Idade Antiga remonta à experiência política em Atenas no período clássico, especificamente na fase da democracia radical (século IV a. C.). De fato, o regime democrático não surgiu concomitantemente àquela cidade-estado, mas se desenvolveu a partir de uma série de revoluções que alteraram as estruturas de poder político e os princípios que pautavam as relações sociais, que culminaram com a substituição do código religioso, que durante séculos informou a atividade do governo, pelo princípio do interesse público. Como esclarece Foustel de Coulanges, "aquilo que os latinos chamam res publica, e os gregos tó koinón, é o que substitui a velha religião. É o que decide o futuro das instituições e das leis, e tudo a que os atos importantes das cidades se reportam" (COULANGES, 1998, p. 360).

Na Grécia antiga foi estabelecido um regime de cidadania e um acervo de ideais que na modernidade serviram de referencial para a teoria política. O regime de participação plena da pólis grega só era exequível em decorrência de aquela estrutura econômica e social conferir ao cidadão tempo livre para se incumbir dos interesses da coletividade. A participação era viabilizada pela cidadania restrita aos homens livres atenienses, que se ocupavam da vida pública enquanto o trabalho de manutenção da vida doméstica era atribuído aos escravos. Participar era, ainda, um compromisso trabalhoso e indeclinável (COULANGES, 1998, p. 248) ${ }^{11}$. É ilustrativo o trecho do discurso no qual Péricles, elogiando os guerreiros mortos no primeiro ano da guerra do

${ }^{11}$ Como afirma Bobbio (1992a, p. 42), "bem vistas as coisas, o cidadão total nada mais é que a outra face igualmente ameaçadora do estado total". Veja-se, a propósito, esta interessante passagem em Coulanges (1998, p. 248): “O Estado não admitia que um homem fosse indiferente aos seus interesses; o filósofo, homem de estudo, não tinha o direito de viver isolado. Era sua obrigação votar na assembléia e, por sua vez, ser magistrado. A certa altura, quando as discórdias se tornaram freqüentes, a lei ateniense não permitia ao cidadão sequer sua neutralidade, antes o obrigava a combater por um ou por outro partido; e a quem quisesse continuar alheio às facções e se mostrasse calmo, a lei aplicava severa pena, como a da perda do direito de cidadania.".

Revista de Direito da Cidade, vol. 08, no 4. ISSN 2317-7721 pp. 1707- $1756 \quad 1712$ 
Peloponeso, caracteriza os seus compatriotas atenienses: "Nós somos, de fato, os únicos a pensar que aquele que não se ocupa da política merece não ser considerado como um cidadão tranquilo, mas como um cidadão inútil. Intervimos todos, pessoalmente, no governo da pólis, quer pelo nosso voto, quer pela apresentação de propostas" (TUCÍDIDES, cap. 1, § 40 apud BENEVIDES, 1996).

A particular configuração do sistema político grego, contudo, deve ser entendida à luz da peculiar noção de liberdade daquela sociedade. A concepção de liberdade em Atenas em tudo difere daquela da modernidade. Como destaca Hannah Arendt (1995, p. 42), "ser livre significava ao mesmo tempo não estar sujeito às necessidades da vida nem ao comando de outro, e também não comandar. Não significava domínio, como também não significava submissão"12.

Com efeito, observa-se um paradoxo histórico quanto ao modelo político ateniense. A sociedade grega, berço de conceitos modernos como cidadania, democracia, igualdade (entre os cidadãos), respeito à lei e interesse público era - à luz destes mesmos conceitos sob o enfoque contemporâneo - extremamente iníqua e autoritária ${ }^{13}$.

Contudo, esses elementos não podem servir de fundamento à rejeição do modelo grego clássico de participação como democrático direto. É inegável que o primeiro registro histórico de participação institucional dos indivíduos nas decisões governamentais é identificado na Grécia do século $V$ a.C., a despeito de a estrutura política da época tornar extremamente restrito o status de cidadão.

O resgate do ideário grego opera-se na idade moderna pela obra de Jean-Jaques Rousseau, considerado o teórico seminal da democracia participativa (PATEMAN, 1992). Sua obra é também usada como referência por aqueles que se opõem à participação popular, apoiados na conclusão do filósofo no sentido de que a democracia é o regime perfeito, mas apenas para "um povo de deuses" (BENEVIDES, 1996, p. 49). A questão acerca da representatividade e da legitimação dos eleitos para exprimir a vontade geral surge em uma passagem sempre citada do Contrato Social, na qual Rousseau repele veementemente toda possibilidade de representação política e recusa o

\footnotetext{
${ }^{12}$ A autora prossegue "Assim, dentro da esfera da família, a liberdade não existia, pois, o chefe da família, seu dominante, só era considerado livre na medida em que tinha a faculdade de deixar o lar e ingressar na esfera política, onde todos eram iguais. É verdade que esta igualdade na esfera política tem muito pouco a ver com o nosso conceito de igualdade; significava viver entre pares e lidar somente com eles, e pressupunha a existência de 'desiguais', e estes, de fato, eram sempre a maioria da população na cidade-estado. A igualdade, portanto, longe de ser relacionada com a justiça, como nos tempos modernos, era a própria essência da liberdade; ser livre significava ser isento da desigualdade presente no ato de comandar, e moverse numa esfera onde não existiam governo nem governados" (ARENDT, 1995, p. 45).

${ }^{13}$ David Held (1987, p. 16), porém, destaca que o legado democrático ateniense não foi imune às críticas dos grandes pensadores gregos que se ocuparam de sua cultura e de suas ideias, tais como Tulcíades (460-399 ac), Platão (427-347 ac) e Aristóteles (384-322 ac).
} 
conceito de liberdade como não interferência:

A soberania não pode ser representada pela mesma razão por que não pode ser alienada, consiste essencialmente na vontade geral e a vontade absolutamente não se representa: ou é a mesma, ou é outra - não existe meio-termo. Os deputados do povo não são, pois, nem podem ser seus representantes; são simples comissários, e nada podem concluir definitivamente. Toda a lei que o povo não tenha ratificado diretamente é nula, não é uma lei. O povo inglês pensa ser livre e muito se engana, pois só o é durante as eleições dos membros do parlamento; assim que estes são eleitos, ele é escravo, não é nada (ROUSSEAU, 1978, livro III, cap. XV).

Dessa passagem podemos extrair os mais importantes aspectos relativos ao tema da participação e da representação política na obra de Rousseau, ideias centrais que ainda repercutem na teoria política. Primeiro, a representação política na atividade legislativa é absolutamente inadmissível, pois não pode ser autêntica; segundo, as leis devem necessariamente ser ratificadas pelo povo para assumir essa qualidade; terceiro, o mandato político deve ter natureza imperativa ${ }^{14}$ e, por fim, a liberdade dos cidadãos tem por pressuposto a participação efetiva no processo decisório do Estado. Esse último ponto é de capital importância.

A noção de liberdade constitui um aspecto basilar da participação no pensamento de Rousseau. Participação política e liberdade são, no seu sistema teórico, conceitos completamente interdependentes. É a partir do momento em que participa, contribuindo para formação da vontade geral - que representa o "substrato comum das vontades individuais" 15 -, que se consuma a liberdade do indivíduo. Liberdade não significa ausência de cerceamentos, mas obedecer a ordens por si mesmo formuladas. É por essa razão que Rousseau afirma que os ingleses só são livres quando das eleições. A liberdade, para Rousseau, é um atributo da própria condição humana. "Renunciar à liberdade é renunciar à qualidade de homem", diz ele. E é por meio da participação política que a liberdade é assegurada. A concepção rousseauniana de liberdade aproxima-se daquela do modelo grego de democracia. É liberdade cívica, política. Sua essência está mais na sua origem - a vontade geral -, do que na forma pela qual é exercida. Até então a liberdade defendida pelos jusnaturalistas liberais, como John Locke, traduzia-se numa abstenção do Estado, e, portanto, só poderia existir na medida em que o poder do soberano fosse limitado. A liberdade no pensamento de Rousseau, de forma diversa, extrai sua essência do fundamento da autoridade, que é a vontade geral. Assim, os homens são livres não pelo fato de não encontrarem obstáculos às

\footnotetext{
${ }^{14} \mathrm{O}$ mandato político imperativo, único admitido na origem da representação, assemelha-se ao mandato de direito privado. Nele, o representante encontra-se estritamente vinculado a quem o elegeu, e só pode atuar dentro dos limites estabelecidos no mandato, sem qualquer liberdade de ação.

${ }^{15}$ Definição de Lourival Gomes Machado, em comentário ao Contrato Social, nota no 88 da edição integrante da Coleção Os Pensadores, São Paulo, Ed. Abril (ROUSSEAU, 1978).
} 
suas ações, mas porque as limitações são impostas por si próprios. A liberdade é exercida pelos indivíduos através da lei e não em virtude das brechas deixadas por ela. A autoridade, portanto, não é incompatível com a liberdade, na medida em que autor do comando e o seu destinatário se confundem (BOBBIO, 1992a) ${ }^{16}$. Esse conceito de liberdade como autodeterminação política é muito importante porque, por um lado, constitui as bases da doutrina da democracia participativa, e, por outro, é elemento crucial da crítica ao seu modelo como opressivo da autonomia individual.

Do acoplamento entre liberdade e igualdade decorrem as diferenças mais relevantes entre o modelo político rousseauniano e o engendrado por seus contemporâneos. As críticas mais severas dirigidas a sua obra têm por alvo sua concepção de liberdade, reputada falaciosa, porque pautada em critérios que viabilizam a tirania, além de fundamentada em um pressuposto igualitário inexequível. Nesse sentido é a formulação crítica de Benjamim Constant (1985), que afirma quanto a Rousseau que, "transportando para os tempos modernos um volume de poder social, de soberania coletiva que pertencia a outros séculos, esse gênio sublime, que era animado pelo amor mais puro à liberdade, forneceu, todavia, desastrosos pretextos a mais um tipo de tirania".

É também no pensamento de Rousseau que se estabelece pela primeira vez, de forma ordenada, a oposição entre participação e representação. A negação da fórmula representativa como mecanismo de legitimação política liga-se à concepção de soberania adotada em sua obra. Jean-Jaques Rousseau foi o principal responsável pela propagação da teoria da soberania popular (MALBERG, 1922, p. 153), que assume papel fundamental na sua formulação do contrato social. De acordo com essa teoria, o poder soberano encontra-se dividido entre os membros da nação uti singuli, por quotas-partes individuais, do que decorre que todas as decisões atinentes ao Estado devem ser tomadas pela totalidade dos cidadãos (MALBERG, 1922).

Como notou Carré de Malberg, após ter partido da premissa de que a representação política é inadmissível, Rousseau é levado a admitir que o governo direto não é praticável em nações maiores que as cidades-estado antigas. Assim, em face da impossibilidade de reunir todos os cidadãos nos Estados modernos, reconhece a necessidade de o povo nomear representantes, mas o fundamento dessa representação é uma necessidade de ordem puramente material, além do que é severamente limitada (MALBERG, 1922, p. 205) ${ }^{17}$.

\footnotetext{
16 "Poder-se-ia dizer, parafraseando os existencialistas, que no contrato o homem se condena ser livre" (TOUCHARD, 1970, p. 91).

${ }^{17 E ́}$ interessante registrar que a representação só é rechaçada por Rousseau quanto à atividade legislativa, sendo admitida para as demais atividades governamentais.
} 
De fato, Rousseau, em várias oportunidades, assume as dificuldades do regime que idealiza, como quando afirma que "não se pode imaginar que o povo permaneça constantemente reunido para ocupar-se dos negócios públicos" (ROUSSEAU, 1978, livro III, cap. VI). Porém, há outro papel atribuído à participação direta com relação ao qual o filósofo não transige. Trata-se da função que assume a ratificação popular como pressuposto de validade da lei, e da concepção que faz do mandato político, que, no seu entender, só pode ter feição imperativa, já que o representante só pode ser considerado mero comissário do eleitor.

Para Rousseau, a incapacidade do povo para legislar em hipótese alguma pode tornar legítimo que alguém assuma essa tarefa em seu lugar. Aquele que redige as leis não tem e não deve ter nenhum direito legislativo, e nem o próprio povo pode, quando o quiser, despojar-se desse direito intransferível. Somente a vontade geral obriga os particulares, e só se pode assegurar que uma vontade particular está de acordo com a vontade do povo após submetê-la ao sufrágio livre (ROUSSEAU, 1978, livro III, cap. VI).

Quanto a este aspecto, a concepção de Rousseau é radicalmente distinta da de Montesquieu - cuja teoria da separação de funções inspirou a engenharia institucional das constituições liberais -, para quem fundamento da representação não reside apenas na impossibilidade material de reunir todos os cidadãos para deliberar sobre as questões de interesse comum, mas, também, e principalmente, na incapacidade do povo para empreender tal tarefa. Montesquieu defende que a fórmula do mandato político é a solução democrática para o problema relativo à inépcia da maioria dos indivíduos quanto a atos de gestão governamental. Ele afirma que "o povo é admirável quando escolhe aqueles aos quais deve delegar uma parte de sua autoridade" (MONTESQUIEU, 1996, livro segundo, cap. II), mas não para governar, e que "assim como a maioria dos cidadãos, que têm pretensão bastante para eleger, mas não para serem eleitos, o povo, que tem capacidade suficiente para fazer com que se prestem contas da gestão dos outros, não está capacitado para gerir" (MONTESQUIEU, 1996, livro segundo, cap. II).

A experiência grega e o pensamento de Rousseau são decisivos na formulação mais recente do conceito de democracia direta ${ }^{18}$. Segundo Karl Loewenstein (1976, p. 95), a "democracia direta é o modelo de governo no qual o povo, ou seja, a totalidade daqueles que segundo a lei e o costume são considerados cidadãos dotados de todos os direitos, se reúne em

\footnotetext{
${ }^{18}$ Como assinalou Carole Pateman (1992, p. 35): "Embora Rousseau tenha escrito antes do desenvolvimento das instituições modernas da democracia, e mesmo que sua sociedade ideal seja uma cidade-Estado não industrial, é em sua teoria que se podem encontrar as hipóteses básicas a respeito da função da participação de um Estado democrático".
}

Revista de Direito da Cidade, vol. 08, no 4. ISSN 2317-7721 pp. 1707- $1756 \quad 1716$ 
assembleias - la ekklesia de dos gregos - ou em comitês para efetivar a função de tomar a decisão política e de controle político, assim como para participar da execução de decisão tomada" ${ }^{19}$. Sartori (1994, p. 32), partindo da premissa de que a democracia direta pode, também, "ser definida simplesmente ao contrário, isto é, como uma democracia sem representantes e sem mecanismos de transmissão de representatividade", afirma que a democracia direta, literal, autenticamente governante, só pode existir em grupos de tamanho limitado, até a dimensão de uma assembleia. Ultrapassados os limites da assembleia, estabelece-se a classificação democracia direta observável e maior que a observável, sendo esta última aquela cuja amplitude inviabiliza a observação direta. A democracia dos antigos, para Sartori, pertence ao primeiro tipo, "pois se constituía não apenas de uma reunião de cidadãos num único lugar, mas também de um comportamento observável dos participantes". E, no caso das democracias diretas maiores que as observáveis, o que as qualifica como diretas "é apenas, ou basicamente, a inferência de que não é um tipo representativo de democracia".

Na teoria política contemporânea, o ideário herdado de Rousseau está hoje representado pelos teóricos da democracia participativa ${ }^{20}$. Essa vertente contesta o peso que a democracia liberal deposita na autonomia individual em comparação com o direito de participar na formação da vontade política. Os democratas participativos entendem que a sociedade contemporânea oferece poucas chances de participar significativamente, e se forem dadas oportunidades para que os cidadãos se engajem na vida política, elas serão aproveitadas e resultarão numa sociedade mais justa e bem ordenada. Como destaca Benjamin Barber as pessoas são "apáticas porque são impotentes, não impotentes porque são apáticas" (1984, p. 272). Para seus defensores, o incremento da participação direta pode servir como contraponto às deficiências do modelo representativo, tais como falta de informação, desinteresse na política e baixo controle dos agentes estatais, prevenindo abusos de poder pelos representantes e incrementando a consciência cívica $^{21}$. A democracia participativa exalta as virtudes de uma cidadania ativa, que pode e deve ser ensinada e incentivada pela atribuição de mais poder às pessoas. Uma das funções mais

\footnotetext{
${ }^{19}$ Como destaca o autor, "Uma distinção clara entre as funções executiva, legislativa e judicial não era conhecida pela teoria ou pela prática da democracia direta, nem teria sido, de fato, compatível com ela. $O$ tipo de democracia direta só poderia caber em uma ordem social relativamente simples e assentada em um território pequeno. A etnologia comparada confirmou amplamente a afirmação de Tácito sobre as primitivas tribos teutônicas na De Germania (XI); "De minoribus rebus principes consultant, de maioribus omnes".

${ }^{20}$ A expressão democracia participativa ganha destaque a partir dos trabalhos de Carole Pateman (1970) e Macpherson (1977).

${ }^{21}$ Vejam-se, por exemplo, Carole Pateman (1970) e Benjamin R. Barber (1984). Veja-se, ainda, uma descrição dessa vertente em Amy Gutmann (2007, p. 526).
} 
importantes da participação é a educativa, bem como a participação é, em si mesma, algo bom e necessário para os indivíduos e a sociedade.

\section{O CONCEITO DE DEMOCRACIA INDIRETA. ALGUNS PRESSUPOSTOS HISTÓRICOS, TEÓRICOS E CONCEITUAIS DA DEMOCRACIA REPRESENTATIVA.}

Apesar de a origem da técnica representativa não ter sido, até hoje, identificada com precisão, os corpos colegiados feudais são, frequentemente, apontados como base histórica das modernas assembleias legislativas. Há referências, ainda, no sentido de que a noção de representação remonta ao direito canônico medieval, cujas regras representativas fundamentais teriam sido assimiladas pela esfera secular (LOEWENSTEIN, 1976, p. 59; KRYMEN, 1987).

De outro lado, é comum afirmar que a teoria de representação democrática só veio a se estruturar com o advento da Revolução Francesa, cujo arcabouço de ideias políticas guarda plena correspondência com o fundamento da democracia indireta, de que o povo exerce o poder por meio de seus representantes (GARCÍA-PELAYO, 1989, p. 179).

Quanto à origem das instituições representativas, Biscaretti di Ruffia aponta os “Parlamentos medievais - constituídos, diretamente ou por representação, pelos três estados da nobreza feudal, dos dignatários eclesiáticos e da classe burguesa..." como "primeiros traços das assembleias legislativas representativas" (RUFFIA, 1984, p. 238-239). Reconhece, entretanto, que esses órgãos - que "adotavam nomes diversos nos diferentes países (Estados Gerais, na França e no Piemonte; Estamentos, na Sardenha; Parlamentos, em Nápoles e na Sicília; Cortes, na Espanha)", e que manifestavam ao Rei as demandas da sociedade que representavam, expondo as reclamações dos súditos quanto aos serviços públicos - encontravam severas limitações à sua atuação pelo fato de os representantes poderem deliberar apenas nos limites do mandato outorgado pelos grupos representados. Esse sistema de mandato imperativo traduzia, portanto, autêntica representação jurídica de vontade ${ }^{22}$.

García-Pelayo afirma que a origem e a estrutura da formação da democracia

\footnotetext{
${ }^{22}$ Apesar de muitos identificarem nesses colegiados medievais as raízes históricas da representação política, a questão em absoluto é pacífica. Para Duguit, por exemplo, é inequívoca a presença da ideia de representação na antiguidade, pois, a despeito de a lei ser votada diretamente pela assembleia popular, "em qualquer lugar em que a intervenção direta do povo é excluída pela natureza das coisas surge a ideia de representação" (apud ACCIOLY, 1981, p. 215). Caso assim não fosse, "os juristas romanos, para quem era absolutamente conhecida a noção de mandato, a teriam incorporado ao seu sistema" (LOEWENSTEIN, 1976, p. 58). Também no sentido de que os antigos desconheceram a representação política, v. MALBERG, 1922, p. 232. Karl Loewenstein (1976), em sentido inverso, afirma que a técnica de representação política foi completamente desconhecida na antiguidade.
} 
representativa estão condicionadas, em síntese, por dois motivos. Primeiro, a impossibilidade técnica da democracia direta, ou seja, da adoção da tese de Rousseau, questão em relação a qual os teóricos da Constituinte de 1789 aderiram ao pensamento de Montesquieu e de De Lolme. Segundo, pela "substituição da ideia de povo como algo tangível e visível pela ideia de nação" (GARCÍA-PELAYO, 1993, p. 179) ${ }^{23}$. Esse segundo ponto é particularmente importante para os debates atuais sobre os limites da participação, pois na teoria da soberania nacional residem as origens da democracia elitista, que rejeita as fórmulas de cidadania ativa.

Com efeito, o princípio representativo encontra-se intrinsecamente ligado à teoria de soberania nacional, formulada por Sieyés, de acordo com a qual o titular da soberania não é o povo, mas a nação, que por sua vez é representada pelo parlamento. Essa teoria rejeita a noção de que o indivíduo é titular de parcela da soberania, e de que as vontades individuais constituem parcelas da vontade nacional. Nação e povo formam uma só entidade abstratamente personificada, que dispõe de vontade autônoma e superior, expressada exclusivamente por meio de seus representantes. Nas palavras pronunciadas pelo próprio Sieyés em discurso na Constituinte, "O povo não pode ter outra voz além da de seus representantes, ele não pode falar, não pode agir se não for por meio deles" (apud CLAVREUL, 1987). Essa doutrina, que perpassa todo o constitucionalismo francês pós-revolucionário, foi proclamada no artigo 3o da Declaração dos Direitos do Homem de 1789, o qual enuncia que "o princípio de toda soberania reside essencialmente na Nação". De outra parte, a Constituição de 1791 confirma a adoção do princípio, ao consignar, no artigo 1o do Título III, que: "A soberania é una, indivisível, inalienável e imprescritível. Pertence à nação; nenhuma seção do povo, nenhum indivíduo pode atribuir-se-lhe o exercício".

Cristalizada a tese de que a Nação é titular absoluta da soberania, e que esta é exercida por meio dos representantes, a participação política dos indivíduos passa a limitar-se à possibilidade de escolha dos governantes. Como afirma Maria Victoria Benevides: "É justamente a ênfase na soberania nacional (e não popular) que ensejará a maioria das polêmicas sobre representação e exercício direto da democracia. Se a nação é representada pelo Parlamento, a ele, exclusivamente a ele, cabe a representação política" (BENEVIDES 1996, p. 53).

A adoção da teoria da soberania nacional tem, ainda, outras duas importantes implicações. Uma consistente na supressão da soberania pessoal do rei, e, consequentemente, de seu poder

${ }^{23}$ Como aduz Eric J. Hobsbawn (1996), "Se a economia do mundo do século XIX foi formulada principalmente sob influência da revolução industrial britânica, sua política e ideologia foram formadas fundamentalmente pela Revolução Francesa.".

Revista de Direito da Cidade, vol. 08, no 4. ISSN 2317-7721 pp. 1707- $1756 \quad 1719$ 
absoluto. Outra - decorrente da substituição da ideia de povo pela de nação - conformada na independência de atuação do representante em relação ao eleitor, da qual resulta a abolição do mandato imperativo. Quanto à primeira implicação, é interessante observar que, a despeito de, sob a perspectiva da teoria democrática, a noção de soberania nacional ter substituído a de soberania popular, cronologicamente a soberania da nação tomou o lugar da soberania pessoal do rei, que tinha por fundamento a doutrina da investidura divina (MALBERG, 1948, p. 892) 24 .

A outra consequência da adoção da teoria da soberania nacional é a formação de um novo conceito de representação, que importou na superação histórica do mandato imperativo, por meio do qual o eleitor determinava, detalhada e antecipadamente, quais as posições que deveriam ser adotadas pelo representante no momento da votação. Por esse instrumento o representante só podia atuar dentro dos estritos limites do mandato que the houvera sido outorgado, de forma que, caso surgisse situação imprevista, ele não poderia prosseguir na deliberação sem antes receber instruções dos eleitores, que podiam, a qualquer tempo, revogar o mandato. Esse sistema foi totalmente suprimido pela Constituição da França de 1791, cujo texto enunciava que "os representantes eleitos nos departamentos não serão representantes de nenhum departamento em particular, mas de toda a nação, e não Ihes poderá ser dado nenhum mandato". Na Inglaterra o sistema perdurou por mais tempo, sendo suprimido o mandato imperativo apenas no século XIX.

Finalmente, quanto ao papel histórico da representação política, é interessante registrar, ainda, que Karl Loewenstein, analisando as origens da técnica da separação de funções e distribuição do poder, afirma que a ideia de distribuição do poder encontra-se essencialmente unida à teoria e à prática da representação. Para ele, foi a representação condição prévia e indispensável para distribuir o poder político entre os detentores do poder, pois implicou a instituição do parlamento como um poder separado e independente do governo. A partir daí, a separação da função judicial foi consequência lógica de todo um sistema de detentores do poder independentes entre si (LOEWENSTEIN, 1976, p. 60).

Tendo em vista tais pressupostos históricos, pode-se afirmar que o traço essencial ao modelo de democracia representativa é o fato de que a titularidade do poder pertence à

\footnotetext{
${ }^{24}$ A respeito desse assunto, assinala Carré de Malberg (1948, p. 892) que: "A Assembleia nacional de 1789, ao fundar o princípio da soberania da nação, se propunha essencialmente a retirar o antigo poder absoluto do rei, para mitiga-lo e restringi-lo, subordinando-o à Constituição e também o repartindo entre o rei e outros órgãos nacionais, especialmente um corpo legislativo eleito e independente do monarca. Com este objetivo, a Constituinte negava ao rei toda a soberania nacional, e coloca a fonte de soberania na nação, de maneira que o rei não poderia, a seguir, exercer o poder senão em nome, por conta e obra da nação, única e soberana.".
} 
coletividade, mas o exercício governamental é atribuído a representantes eleitos pelos cidadãos, os quais atuam com independência e sem vinculação àqueles que os elegeram, por tempo determinado. É importante ressaltar, ainda, que representação e democracia são conceitos autônomos e não correspondentes. Como assinala Bobbio, da mesma forma que "nem toda forma de democracia é representativa", "nem todo estado democrático é democrático apenas pelo fato de ser representativo" (BOBBIO, 1992, p. 45).

A noção de democracia representativa prende-se, basicamente, a três ordens de ideias: primeiro, a de que o poder político é exercido por intermediários, e não diretamente pelo povo, efetivo titular do poder; segundo, a de que a escolha desses intermediários é feita mediante a participação de todos os indivíduos no gozo dos direitos políticos, e dentro do sistema do sufrágio universal; e, terceiro, de que o mandato político é livre e os representantes atuam com independência, desvinculados dos interesses privados daqueles que os elegeram.

Do ponto de vista teórico, a representação liga-se às perspectivas elitistas da democracia. Como se viu, a ideia de que o povo é incapaz de comandar seu próprio destino está presente desde o aparecimento da técnica da representação parlamentar, que se lastreia não apenas na impossibilidade prática da democracia direta, mas também na conviç̧ão de que nem todos os indivíduos estão habilitados para decidir os rumos da política. A teoria da democracia elitista recente tem raiz nos trabalhos de Gaetano Mosca (1939), Vilfredo Pareto (1935) e Robert Michels (1982), que buscaram justificar a autoridade dos líderes políticos a partir da análise empírica dos governos da Europa no final do século XIX. Para eles, a desigualdade natural entre as pessoas é um dado que torna inevitável a formação de oligarquias, razão por que qualquer sociedade é dívida entre a elite governante e as massas. As primeiras são recrutadas nos estratos mais elevados da sociedade, perpetuando-se no poder por suas habilidades e capacidade de organização. O elitismo clássico, na sua essência, é incompatível com a noção contemporânea de democracia. A busca da conciliação da tradição elitista com o pluralismo e o ideal democrático aparece nas teorias de Joseph Schumpeter (1984) e Robert Dahl (1992 e 1997). Esses autores vislumbram nas estruturas democráticas fórmulas de competição e seleção de elites governantes que resultam em sistemas estáveis. Joseph Schumpeter extrai das teorias elitistas a ideia de que mesmo nas democracias as elites comandam, mas afirma que a existência de um consenso na elite, que se autolimita por procedimentos democráticos. Esses procedimentos funcionam como um filtro que evita a manipulação das massas por demagogos que explorem seus preconceitos e emoções ${ }^{25}$. 0 modelo

${ }^{25}$ Pateman (1992, p. 12) explica que, para Schumpeter: "democracia é um método político, ou seja, trata-se 
elitista pode ser resumido na afirmação do autor de que o método democrático é "o arranjo institucional para chegar às decisões políticas no qual os indivíduos adquirem poder de decidir por meio de uma batalha competitiva pelos votos do povo". Robert Dahl, por sua vez, vê o governo como um árbitro neutro de uma dinâmica competitiva que decorre do pluralismo social. A ampliação da competição e as relações estratégicas, calcadas no interesse dos atores políticos e dos eleitores, coopera para a dinâmica democrática, pois a disputa pelos votos gera tolerância com os adversários e equilíbrio de forças. Na visão de Dahl, as oligarquias não desapareceram, mas estão fragmentadas, compondo um conjunto de minorias com variados tamanhos e potências políticas (a poliarquia). Os democratas elitistas não creem em qualquer funcionalidade ética ou educativa da democracia, nem tampouco vislumbram na participação popular um meio para construir uma sociedade bem ordenada. Ao contrário, um certo nível de indiferença é tido como desejável e necessário para a manutenção da estabilidade democrática, bem como para evitar decisões lastreadas em emoções e na manipulação de grupos desinformados.

Ao longo da história do constitucionalismo liberal, estabeleceu-se uma forte associação entre a dinâmica representativa e o modelo democrático, especialmente aquele calcado nas teorias de matriz elitista. Todavia, desde o início da formação das próprias instituições representativas foi percebida a insuficiência destes meios em atender aos anseios dos ideais democráticos em sua plenitude. Assim, ainda no limiar da implantação da democracia representativa, começaram a se formar as bases para a instituição dos modelos de democracia semidireta.

\section{AS FÓRMULAS DE DEMOCRACIA SEMIDIRETA E A APROXIMAÇÃO ENTRE DEMOCRACIA PARTICIPATIVA E DELIBERATIVA.}

Não há dúvida que a democracia direta, em sua forma antiga, é inviável no contexto contemporâneo. No século XVIII, quando os Federalistas propuseram a substituição da democracia dos antigos pela República, a democracia representativa foi apresentada como única alternativa factível para concretização dos valores democráticos. Entretanto, quase que simultaneamente à consolidação prática e teórica da democracia representativa, no exórdio do constitucionalismo, surgem as raízes de instrumentos de participação direta, cuja combinação com a fórmula da

de um determinado tipo de arranjo institucional para se chegar a decisões políticas, legislativas e administrativas e, portanto, não pode ser um fim em si mesmo, não importando as decisões que produzem sob condições históricas dadas".

Revista de Direito da Cidade, vol. 08, no 4. ISSN 2317-7721 pp. 1707- 1756 
representação constitui o que atualmente denomina-se democracia semidireta.

Como bem observou Aguiar de Luque $(1977)^{26}$, a democracia representativa não implica renúncia à participação direta, uma vez que desde o começo do movimento constitucional foram criados certos institutos que, inspirados na democracia direta, tinham por objetivo colocar em prática a participação popular direta, ainda que lhes conferindo caráter excepcional e reservado a questões de relevância extraordinária, com o propósito de por meio deles formar uma base de legitimidade democrática no Estado constitucional (LUQUE, 1977, p. 9).

No plano teórico, a paternidade dos institutos de participação direta é atribuída, em geral, a Condorcet, liberal de inspiração rousseauniana, que se inclina na direção de um sistema representativo, mas com exceções (LUQUE, 1977, p. 30-31)27. A mais remota referência à participação direta durante a modernidade menciona as colônias inglesas da América do Norte, nos primeiros momentos de sua fundação. Como informa Luque, eram comuns convenções que serviam como atos fundacionais das novas colônias - a exemplo daquela subscrita pelos Padres Peregrinos antes de deixar o Mayflower em 1620 - por meio das quais juravam permanecer juntos e obedecer às regras estabelecidas por uma vontade comum para o bem comum (LUQUE, 1977, p. $33)^{28}$.

De outro lado, a referência mais importante à participação direta na Idade Moderna - e de forma combinada com a representação - pode ser verificada no artigo 6ㅇ da Declaração dos Direitos do Homem e do Cidadão, de 1789 - de autoria de Talleyrand e aprovado por unanimidade pela Assembleia - o qual, combinando elementos do pensamento de Rousseau e de Montesquieu, enuncia que "a lei é expressão da vontade geral" e que "todos os cidadãos têm o direito de concorrer pessoalmente ou através de seus representantes" (RODRIGUES, 1994, p. 57).

A Constituição de 1791, entretanto, não absorveu essa exceção ao princípio representativo, a despeito de vários constituintes franceses terem defendido propostas neste sentido, uma vez que consagrou, em sua essência, o pensamento de Siéyes, defensor ferrenho da democracia representativa, e que chegou a aquilatar a participação direta de "democracia bruta" (RODRIGUES, 1994). Ainda durante a Revolução, a partir da Convenção, foi completamente abolida

\footnotetext{
${ }^{26}$ A propósito da evolução histórica dos mecanismos de participação direta, vale a pena consultar esse precioso trabalho de Aguiar de Luque, apresentado como tese de doutoramento, sob a orientação de Luis Sánchez Agesta. A monografia abrange, ainda, meticulosa análise de direito comparado.

${ }^{27}$ Porém, como já foi salientado neste trabalho, o próprio Rousseau lançou as bases teóricas de tal sistema.

${ }^{28}$ Contudo, pondera o autor que tais atos parecem menos ligados à teoria de participação do que à expressão puritana de uma das teses de Calvino, que partindo da plena liberdade religiosa do indivíduo, considerava que as Igrejas poderiam ser fundadas entre homens que subscrevessem um acordo.
} 
a monarquia e tornou-se necessário fundar um novo regime, ancorado em base legitimadora diversa, a qual, provavelmente, extrai a sua essência do pensamento rousseauniano. O Comitê de Constituição, sob maioria girondina, elaborou um projeto essencialmente representativo, mas com elementos semidiretos. Essa fórmula que mesclava essência representativa com elementos de participação explica-se pelo fato de que Condorcet foi o principal articulador do projeto.

É no fim do século XIX e início do século XX que a participação direta volta a ser um tema importante, sendo consagrada na Constituição de Weimar, e, por esta via, absorvida nas Constituições do período entre guerras. Por outro lado, na Suíça, a participação direta consolidouse através de paulatina evolução, e no século XIX positivou-se pelo instituto do referendum e da iniciativa popular (LUQUE, 1977, p. 50) ${ }^{29}$.

Na França, a participação direta, no século XIX, foi utilizada como instrumento para legitimar a atuação política dos governantes. Napoleão Bonaparte e Luiz Napoleão fizeram largo uso das consultas populares, sob a denominação de plebiscito, o que deu origem ao termo democracia plebiscitaria ou cesarismo plebiscitário, de caráter altamente pejorativo. Esses acontecimentos serviram, e servem até hoje, como fundamentos históricos às críticas formuladas em relação aos mecanismos de democracia semidireta.

No século $X X$, mais especificamente, no imediato pós-guerra, as instituições de participação direta foram utilizadas como mecanismos de legitimação e consenso dos regimes constitucionais forjados a partir do vácuo político e jurídico deixado pela derrota militar do nazismo (LUQUE, 1977, p. 9). A participação direta combinada com a representação é, portanto, uma característica marcante do Direito Constitucional entreguerras.

A partir de então, quase todas as Constituições europeias preveem ao menos uma modalidade de participação política direta, a caracterizar o sistema misto, cujo traço essencial é exatamente a combinação da representação tradicional moderna com instrumentos inspirados nos ideais da democracia direta clássica.

Precisamente pelo fato de os instrumentos de participação direta só serem exequíveis num contexto de complementaridade da representação política tradicional é que se afigura mais correto enquadrá-los como pertencentes à democracia semidireta. Assim, podem ser qualificados como manifestações de democracia semidireta os seguintes instrumentos: o referendo, o

\footnotetext{
${ }^{29}$ Como informa o autor, a locução "referéndum" tem origem na Idade Média, e remonta ao antigo Direito Suíço que previa que os delegados dos cantões quando, não tinham instruções sobre como proceder a nível federal, tomavam suas decisões "ad referendum", ou seja, condicionada à aprovação ratificadora das populações dos cantões do qual provinham.
} 
plebiscito, a iniciativa popular, o recall e veto popular.

\section{CONCEITO, TRAJETÓRIA E CONFIGURAÇÃO DA INICIATIVA POPULAR NO DIREITO BRASILEIRO. PROPOSTAS DE REFORMULAÇÃO PARA INCENTIVAR A UTILIZAÇÃO DO INSTITUTO.}

A iniciativa popular é uma etapa do processo legislativo. O processo legislativo, ou, como preferem alguns, procedimento legislativo ${ }^{30}$, é um conjunto encadeado de atos ou etapas necessárias à formação da lei em sentido formal ${ }^{31}$. No iter que constitui o procedimento legislativo, a iniciativa é o ato inaugural ${ }^{32}$. José Afonso da Silva (1964, p. 107) define-a como "o ato inicial do processo legislativo com vista a uma modificação ou inovação na ordem jurídica preexistente". Destaca Canotilho (1998, p. 766) que a função desta etapa é "colocar em andamento o poder legislativo, fornecendo-lhe o impulso jurídico necessário para a sequência procedimental".

\footnotetext{
${ }^{30}$ Não há uniformidade na doutrina quanto ao emprego da locução processo legislativo. Os autores europeus utilizam com maior frequência - e reputam mais adequada - a expressão procedimento legislativo. cf. MIRANDA, 1990, p. 34. No Brasil, José Afonso da Silva (1985, pp. 458 e 462) adota a nomenclatura processo legislativo para "o conjunto de atos realizados pelos órgãos legislativos visando a formação das leis constitucionais, complementares e ordinárias, resoluções e decretos legislativos", e procedimento legislativo para "o modo pelo qual os atos do processo legislativo se realizam".. Manoel Gonçalves Ferreira Filho (1995, p. 192), por sua vez, critica a expressão processo legislativo, apregoando que seria mais correto empregar a expressão processo normativo. No presente estudo as locuções processo legislativo e procedimento legislativo são utilizadas como sinônimas.

${ }^{31}$ Canotilho (1998, p. 765) assim define o processo legislativo "Designa-se por procedimento legislativo a sucessão de série de actos (ou de fases, consoante a posição doutrinal respeitante a natureza do procedimento) necessários para produzir um acto legislativo. A lei é o acto final do procedimento. As várias fases procedimentais, disciplinadas com maior ou menor particularização nos vários ordenamentos, estão pré-ordenadas à produção de um acto final, a que chamamos lei formal de Assembleia. Deste modo, o procedimento legislativo é um complexo de actos, qualitativa e funcionalmente heterogéneos e autónomos, praticados por sujeitos diversos e dirigidos à produção de uma lei do Parlamento. Noutros termos: procedimento legislativo é a forma da função legislativa, isto é, o modo ou iter segundo o qual se opera a exteriorização do poder legislativo.

32 É praticamente pacífica na doutrina a concepção de que a iniciativa é o ato deflagrador do processo legislativo. Entretanto, quanto à identificação e à conceituação das demais fases, há diferenças razoáveis entre os doutrinadores. Canotilho (1998, p. 765) elenca três fases procedimentais: (1) fase de iniciativa; (2) fase constitutiva e (3) fase de ativação ou integração de eficácia. Relata o autor português, porém, que outros preferem aludir a cinco fases, ordenadas da seguinte forma: a) fase de iniciativa; b) fase instrutória, na qual incluem fundamentalmente atos de consulta; c) fase constitutiva, na qual incluem os atos de formação da vontade (discussão e votação); d) fase de controle, destinada a avaliar do mérito e de conformidade do ato legislativo; e) fase de comunicação, cuja finalidade principal é dar publicidade e tornar obrigatório o ato legislativo. No Brasil, Manoel Gonçalves Ferreira Filho (1995, p. 202) adota classificação semelhante à de Canotilho, mas afirma que, juridicamente, a iniciativa não é propriamente uma fase do processo legislativo. José Afonso da Silva (1985, p. 458), por sua vez, identifica, no processo legislativo, os seguintes atos: iniciativa, discussão, votação, sanção ou veto, promulgação e publicação. Essa última classificação afigura-se, de fato, a mais satisfatória, pois divide analiticamente as etapas fundamentais e indispensáveis ao procedimento regular de formação da lei.
} 
Nos primórdios da história da atividade legislativa, apenas ao governo competia provocar a atuação do Parlamento. As primeiras estruturas parlamentares modernas, derivadas dos corpos colegiados medievais, não produziam normas jurídicas no sentido atual, mas tinham função principal aprovar as decisões dos soberanos (SILVA, 1985, p. 115). Os parlamentares não podiam, nesse sistema, apresentar projetos de leis, pois se limitavam a deliberar acerca de proposições genéricas do monarca, as quais, uma vez aprovadas, eram transformadas em atos legislativos pelo próprio soberano.

O advento do constitucionalismo liberal alterou radicalmente essa fórmula, tendo em vista o intenso fortalecimento dos Parlamentos que the é subjacente, respaldado nas formulações teóricas de Montesquieu ${ }^{33}$. A partir de uma leitura rígida da separação de poderes, a iniciativa das leis só pode caber ao próprio parlamento.

As mutações da teoria de separação de poderes decorrentes culminaram na ideia de colaboração entre os poderes, tornando obsoleta a tese do monopólio do exercício da iniciativa pelos parlamentares (CLÉVE, 1993, p. 96). Nesse contexto, a titularidade do poder de iniciativa legislativa passa a ser compartilhada por vários sujeitos constitucionais (CANOTILHO, 1998, p. 767), com especial destaque para o Poder Executivo, que, além de adquirir o poder de iniciar o procedimento legislativo, passa também editar normas ${ }^{34}$.

No processo legislativo brasileiro, assim como em praticamente todos os modelos contemporâneos de constitucionalismo democrático ${ }^{35}$, o poder de iniciativa é compartilhado por diversos atores institucionais. Assim, o sistema de iniciativa no Brasil pode ser qualificado utilizando-se a terminologia empregada por Canotilho (1998, p. 767) - como um sistema de iniciativa pluralística, "dado que o poder de iniciativa é constitucionalmente atribuído a vários órgãos (sujeitos constitucionais) ". De acordo com o artigo 61 da Constituição de 1988, a iniciativa das leis complementares e ordinárias cabe a qualquer membro ou Comissão da Câmara dos

33 Como observa Manoel Gonçalves Ferreira Filho (1995, p. 142): “Em O espírito das leis, a iniciativa é reservada ao Legislativo. Nenhum outro poder, nem o executivo, nem o Judiciário, em hipótese alguma pode apresentar projetos que alterem o direito existente, ou apresentar, à aprovação das câmaras, a sugestão de normas jurídicas novas". Destaca o autor o fato de que, nos Estados Unidos, essa concepção encontra-se perfeitamente expressa. Todavia, averba que embora o Presidente não disponha do poder de iniciativa, é ainda assim o proponente da maior parte da legislação, operando por meio de deputados que encampam os projetos e os apresentam.

34 É importante ressaltar que essa nova força do Executivo na idade contemporânea é fruto de um longo processo histórico em que operaram reformas jurídicas e mutação constitucional. Como assinala Carlos Roberto de Siqueira Castro (1996), as alterações na balança da supremacia entre as instituições deram-se mais no plano fático da realidade política que no plano jurídico positivo, eis que não foram realizadas às custas de profundas reformas constitucionais.

35 Registre-se a exceção relativa aos Estados Unidos, no âmbito federal. 
Deputados, do Senado Federal ou do Congresso Nacional, ao Presidente da República, ao Supremo Tribunal Federal, aos Tribunais Superiores, ao Procurador-Geral da República e aos cidadãos, na forma e nos casos nela previstos.

A capacidade de apresentar proposições legislativas qualifica-se juridicamente como um poder/competência constitucional e como um direito político fundamental ${ }^{36}$. Quando exercida pelos mandatários e representantes políticos, predomina a faceta poder/competência. Quando utilizada pelos cidadãos para mobilizar o aparelho legislativo, fica mais visível sua natureza de direito político.

O poder de iniciativa para deflagrar o processo legislativo é um importante instrumento de governo. Legislar, em muitos cenários, é sinônimo de governar. Dessa forma, a distribuição dessa faculdade entre diversos atores políticos evidencia uma tendência democrática e de promoção do pluralismo. Nessa ordem de ideias, a participação popular no procedimento de elaboração da lei constitui um dos mais eficazes instrumentos de democracia semidireta, pois implica a possibilidade de o corpo eleitoral impor uma agenda ao Parlamento. Como ressalta José Afonso da Silva (1985, p. 124), “(...) a iniciativa das leis funciona como instrumento de atuação do programa político ideológico".

A aplicação de mecanismos de democracia semidireta no constitucionalismo brasileiro foi, até o advento da Carta de 1988, esporádica e pouco debatida. Apesar do fato de que, como verificou Benevides (1996, p. 111) - "propostas de criação de formas de democracia semidireta não são inéditas em nossa história política, assim como não se restringem ao ideário jacobino ou das 'esquerdas' em geral" - o modelo de governo representativo prevaleceu desde o primeiro momento da história constitucional brasileira.

De qualquer forma, é importante lembrar que, na maior parte de nossas constituições, mesmo o princípio da representação não passava de retórica, visando a disfarçar o autoritarismo nem sempre velado e a crônica exclusão do povo do processo político, ora mediante a manipulação oligárquica e a institucionalização da fraude eleitoral, ora por meio da ditadura pura e simples. De fato, no curso da história constitucional brasileira, o princípio da representação, presente na constituição formal, em raros momentos concretizou-se na constituição real ${ }^{37}$.

\footnotetext{
${ }^{36}$ Nesse sentido, afirma Canotilho (1998, p. 767) que a iniciativa "concebe-se juridicamente como um poder (rectius: direito-poder), pois o poder dos deputados, do governo (...) é-lhes atribuído diretamente pela constituição para a realização do interesse público (...)".

37 Uma experiência remota de iniciativa popular na história brasileira foi prevista na Constituição do Estado de Minas, de 14 de julho de 1947, a qual autorizava a deflagração do procedimento legislativo mediante
} 
Um momento particularmente prolífico para a participação popular foi o período que antecedeu e resultou na aprovação da Constituição de 1988. No contexto de democratização que antecedeu a convocação e a instalação da Assembleia Constituinte, com amplos debates sobre diversos temas constitucionais, foi inevitável a emergência da discussão sobre a participação popular direta nas decisões governamentais, tida por muitos como pressuposto fundamental de fortalecimento das instituições democráticas que começavam a ser delineadas.

Com efeito, naquele período ímpar de nossa história política, ocorreu intensa mobilização da sociedade civil, mediante a formação de diversos fóruns de debates, plenários e comitês próparticipação popular, os quais formularam inúmeros projetos e sugestões para a elaboração do texto constitucional. O espaço público nunca estivera tão democratizado. As aspirações populares ali vocalizadas redundaram, em várias oportunidades, em compromissos por parte dos constituintes. Nas discussões travadas teve especial destaque a necessidade de ampliação da participação popular, e se evidenciou a insatisfação com os mecanismos de representação tradicional (DALLARI, 1985 e 1998, p. 190).

As discussões em torno da elaboração da nova Carta deram origem a diversos projetos de Constituição, articulados por juristas e partidos políticos. Em muitos deles era consagrada a iniciativa popular, e quase todos contemplavam pelo menos algum mecanismo de participação direta. No projeto elaborado por Fábio Konder Comparato, sob encomenda do Partido dos Trabalhadores - que o acolheu com modificações - os instrumentos de participação tinham amplo destaque. Nesse texto, a iniciativa popular estava prevista expressamente como direito do cidadão (art. 11) e era admitida tanto para emendas constitucionais como para leis complementares e ordinárias, sendo necessárias 30.000 assinaturas para as primeiras (art. 234), e 10.000 assinaturas para as legislativas (art. 133) ${ }^{38}$. O projeto que o partido veio a apresentar com base no texto do jurista previu a iniciativa popular, mas com número de assinaturas exigido em termos percentuais e não em números absolutos, sendo de 0,5\% do eleitorado para leis (art.141) e 1\% para emendas constitucionais (art. 251). Estabelecia, ainda, a necessidade de referendo para que as emendas

iniciativa subscrita por pelo menos dez mil eleitores. (HORTA, 1995).

38 Em conferência promovida para fornecer subsídios ao debate constituinte, Dalmo Dallari (1986), que se destacou como ferrenho defensor das instituições de democracia semidireta, afirmou: "O que verificamos hoje é que em grande parte a previsão de Rousseau se realizou. Especialmente a partir do século XIX enveredamos pelo caminho dos partidos políticos, e começamos a exigir a participação do povo através de partidos políticos. E chegamos a um ponto em que o partido não é mais um representante do povo, ele é um substituto do povo, e aquilo que no começo se propunha como democracia, degenerou em partidocracia. $\mathrm{E}$ assim decisões da mais alta relevância são tomadas sem que o povo participe e sem que o povo saiba exatamente por que foram tomadas". 
constitucionais entrassem em vigor (art. 252).

Outro projeto a estabelecer a participação direta foi o elaborado por José Afonso da Silva (mimeo) - integrante da Comissão Afonso Arinos, nomeada pelo então Presidente José Sarney que contemplava os institutos do referendo, do veto popular, da revogação dos mandatos e da iniciativa popular tanto no âmbito federal (art. 73), como no estadual e no municipal (art. 78), e, ainda, estabelecia a participação do povo na solução de problemas nacionais como princípio da organização política (art. 5ㅇ). Nesse texto, a iniciativa popular era exclusivamente legislativa e necessariamente articulada, sendo exigidas 50.000 assinaturas (art. 74). De outro lado, previa o projeto a possibilidade de que, mediante petição assinada por 10.000 eleitores, qualquer lei aprovada pelo Legislativo fosse submetida a referendo (art. 75, II).

O anteprojeto formulado por Luís Pinto Ferreira admitia a iniciativa popular em matéria legal (art. 113) e constitucional (art. 106), sendo exigidas em ambas as hipóteses um projeto articulado, assinado por no mínimo 50.000 cidadãos. Tal qual o projeto de José Afonso da Silva (1985), previa a possibilidade de os eleitores requisitarem referendos para ratificação de leis e, também, de emendas constitucionais, mediante petição contendo 50.000 assinaturas (art. 107, $\S 3$ ) .

Outro importante capítulo da história da participação política direta na experiência constitucional brasileira ocorreu quando a Assembleia Constituinte - que fora instalada em março de 1987 - cedendo a pressões da sociedade civil, passou a admitir, em seu Regimento Interno, a apresentação de emendas populares ao texto em elaboração. De acordo com o artigo 24 do Regimento Interno da Constituinte poderiam ser apresentadas propostas de emenda ao projeto de Constituição, desde que subscritas por no mínimo 30.000 eleitores, em listas organizadas por pelo menos três entidades associativas, responsáveis pela idoneidade das assinaturas. Dentre as inúmeras propostas apresentadas, as três que versavam sobre a inclusão no texto constitucional de institutos de participação direta conseguiram reunir um dos números mais expressivos de assinaturas, com 400.000 adesões (BENEVIDES, 1996, p. 125). A despeito de, no período de discussão das emendas populares na subcomissão de Direitos Políticos, dos Direitos Coletivos e Garantias, vários parlamentares terem se mostrado radicalmente contrários a adoção de institutos de democracia semidireta (BENEVIDES, 1996, p. 125), o primeiro projeto de Constituição elaborado pela Comissão de Sistematização (Projeto A) contemplava a iniciativa popular tanto em matéria constitucional como em legislativa - ordinária e complementar - sendo necessárias assinaturas de 0,3\% do eleitorado, distribuídos em pelo menos cinco Estados, com não menos de 0,5\% dos 
eleitores de cada um deles (art. 75). Admitia, ainda, a realização de referendo para anulação total ou parcial de emenda constitucional ou de lei, mediante petição subscrita por $2 \%$ do eleitorado e determinação do Presidente da República (art. 75, § 4ㅇ). O Projeto B de Constituição, aprovado em julho de 1988, excluiu a iniciativa popular em matéria constitucional, aumentou o número de assinaturas necessárias para $1 \%$ do eleitorado e retirou a possibilidade de realização de referendo mediante requerimento popular ${ }^{39}$. Essa sistemática foi a que veio a prevalecer. Como resumiu Dallari (1989, p. 387), "a participação popular conquistou a participação popular".

A Constituição de 1988 inovou quanto à forma de exercício da soberania, ao estabelecer, no parágrafo único de seu artigo 1ำ, que "todo poder emana do povo, que o exerce por meio de representantes eleitos ou diretamente, nos termos desta Constituição". Apesar de o princípio da soberania popular não constituir novidade na história constitucional brasileira, pois foi mencionado em todas as cartas republicanas, pela primeira vez foi enunciada de forma expressa exceção ao princípio representativo, admitindo-se que o poder seja "diretamente" exercido pelo povo. O desdobramento da previsão do artigo 1 o encontra-se no artigo 14 da Constituição, que abre o Capítulo dos Direitos Políticos enumerando três formas de exercício da soberania popular: plebiscito, referendo e iniciativa popular. ${ }^{40}$

A iniciativa popular encontra-se disciplinada, de forma genérica, pelo artigo $61, \S 2 \stackrel{0}{ }$, da Constituição, que a prevê "pela apresentação à Câmara dos Deputados de projeto de lei subscrito por, no mínimo, um por cento do eleitorado nacional, distribuído pelo menos por cinco Estados, com não menos de três décimos por cento dos eleitores de cada um deles". Outros dois dispositivos pertinentes ao instituto fazem menção expressa à sua aplicabilidade aos Estados e Municípios. Trata-se dos artigos $27, \S 40$ e $29, \mathrm{Xl}$, que se referem, respectivamente, à iniciativa

\footnotetext{
${ }^{39}$ Relata José Álvaro Moisés (1990, p. 86) que foi o Centrão que não aceitou a proposta da Comissão de sistematização que estabelecia a exigência mínima de 0,3\%. Observa o autor que, quanto a esse aspecto, a proposta era mais avançada que a do PT, que previa a exigência de $0,5 \%$.

${ }^{40}$ Entre os autores brasileiros, em linhas gerais, prevalece o entendimento no sentido de que o referendo consubstancia consulta relativa a uma criação legislativa, seja projeto de lei ou norma já debatida pelo corpo parlamentar, consistindo a aprovação popular em requisito de validade do ato. O plebiscito, noutro plano, é o mecanismo empregado para consultas de caráter geral e relativas a fatos, ficando a elaboração legislativa, se for o caso, condicionada ao seu resultado. A controvérsia no Brasil foi encerrada, ao menos no âmbito jurídico, com o advento da recente Lei no 9.709, de 18 de novembro de 1998, que positivou as definições dos institutos do plebiscito e do referendo em seu artigo 2으, cujo teor é o seguinte: "Art. 20 o Plebiscito e referendo são consultas formuladas ao povo para que delibere sobre matéria de acentuada relevância, de natureza constitucional, legislativa, ou administrativa: $\S 1$ 10 O plebiscito é convocado com anterioridade a ato legislativo ou administrativo, cabendo ao povo, pelo voto, aprovar ou denegar o que the tenha sido submetido. $\S 2$ o O referendo é convocado com posteridade a ato legislativo ou administrativo, cumprindo ao povo a respectiva ratificação ou rejeição".
} 
popular estadual e municipal. Porém, é importante ressaltar que mesmo que não houvesse previsão específica no texto constitucional quanto à aplicação da iniciativa nas esferas estadual e municipal, os ordenamentos dessas unidades não poderiam deixar de contemplá-la. Primeiro, porque, assim, como os demais instrumentos de democracia semidireta, é um direito político fundamental, cuja aplicação não pode ser diferenciada segundo a esfera de governo ${ }^{41}$, aplicandose indistintamente a todas as unidades da federação. E, também, porque a iniciativa é parte do procedimento legislativo, e as normas gerais a ele relativas são aplicáveis a todos os entes da federação ${ }^{42}$, dado que são princípios constitucionais centrais ${ }^{43}$.

A Lei 9.709/98 dedicou dois artigos à iniciativa popular, estabelecendo três enunciados complementares à Constituição. Primeiro, a exigência de que o projeto de lei de iniciativa popular circunscreva-se a um só assunto. Segundo, a imposição de que ele "não poderá ser rejeitado por vício de forma, cabendo à Câmara dos Deputados, por seu órgão competente, providenciar a correção de eventuais impropriedades de técnica legislativa ou de redação". Por fim, determina a lei que "a Câmara dos Deputados, verificando o cumprimento das exigências estabelecidas no art. 13 e seus parágrafos, dará seguimento à iniciativa popular, consoante as normas do Regimento Interno". ${ }^{44}$

No plano estadual, determina o artigo 27, VI, da Constituição, que "a lei disporá sobre a iniciativa popular no processo legislativo estadual". Quanto aos municípios, o artigo 29, IX, prevê a "iniciativa popular de projetos de lei de interesse específico do município, da cidade ou de bairros, através de manifestação de, pelo menos, cinco por cento do eleitorado".

Pela redação dos dispositivos mencionados verifica-se que a Constituição conferiu às entidades federativas autonomia para regulamentar a iniciativa popular. Essa sistemática, aliás, guarda plena correspondência com o princípio federativo. No caso dos municípios, o texto constitucional estabelece o número de assinaturas necessário, deixando os demais aspectos na

\footnotetext{
${ }^{41}$ Aliás, o diploma legal que disciplina a aplicação dos institutos de democracia semidireta (Lei no 9.709/98) explicita essa realidade, eis que, quanto ao referendo e plebiscito, assim dispõe: "Art. 6o Nas demais questões, de competência dos Estados, do Distrito Federal e dos Municípios, o plebiscito e o referendo serão convocados de conformidade, respectivamente, com a Constituição Estadual e com a Lei Orgânica".

${ }^{42}$ Decidiu o STF nesse sentido inúmeras vezes, cfr. RTJ 144/24, RDA 197,152, RDA 197/215, RTJ 156/777, RDA 199/173, RTJ 159/735 e outros.

${ }^{43}$ Como afirma Raul Machado Horta (1995, p. 390), "normas constitucionais federais, que, transpondo o objetivo primário de organizar a Federação, vão alcançar o ordenamento estadual, com maior ou menor intensidade, demonstram a existência de uma forma especial de normas na Constituição Federal, que denominamos de normas centrais. As normas centrais podem exteriorizar-se nos "princípios desta Constituição", na referência da Constituição de 1988 (...)".

${ }^{44} \mathrm{Um}$ exame detalhado das normas do regimento interno e das restrições por ele estabelecidas pode ser encontrada no excelente trabalho de Humberto Laport de Mello (2013, p. 275-278).
} 
esfera de decisão do legislador local. Para os Estados a liberdade regulamentar é ainda mais ampla ${ }^{45}$, já que a Constituição não prescreveu qualquer regra de funcionamento do instituto nesse âmbito ${ }^{46}$.

Apresentada a configuração geral do instituto, cabe examinar que tipo de limites são impostos ao uso das iniciativas, bem como especular sobre que mudanças não poderiam reverter o quadro de baixa aplicação. O sistema brasileiro estabelece alguns limites importantes ao uso da iniciativa popular. Ela foi prevista expressamente pela Constituição de 1988 apenas para apresentação de projetos de leis ordinárias e complementares, sem abarcar as emendas constitucionais. Paralelamente, o uso das iniciativas populares é restringido pelo fato de a constituição estabelecer um acervo amplo de matérias de iniciativa privativa, dentre as quais se destacam as atribuídas ao Poder Executivo, elencadas no $\S 10$ do artigo $61^{47}$. Essa restrição é aplicável tanto na esfera federal como na estadual e municipal, pois é tida como absorção compulsória pelas unidades federativas, segundo a restritiva jurisprudência do STF ${ }^{48}$. Por outro lado, a Lei 9.709/98 contempla o requisito de unidade temática. O Regimento Interno da Câmara dos Deputados vai além, enumerando uma série de requisitos de ordem formal e procedimental

\footnotetext{
${ }^{45}$ Com a ressalva das restrições decorrentes do sistema federativo, decorrentes normas que, pela aplicação do princípio da simetria, são de absorção compulsória pelos Estados e Municípios. É o caso, e.g. das normas relativas ao processo legislativo (especialmente matérias de competência privativa).

${ }^{46}$ A propósito, não há dúvida quanto ao fato de que ao legislador estadual, e não ao federal, compete a regulamentação da matéria nessa esfera. Essa não só é a mais lógica, mas é a única interpretação que se pode extrair da Constituição. Quanto ao assunto, afirma Dallari (1989) que: “Com efeito, se a competência fosse federal, deveria ser estabelecida entre os dispositivos que tratam do Poder Legislativo da União. E, no entanto, a matéria foi inserida no capítulo que trata no capítulo que trata exclusivamente dos Estados. Além disso, o parágrafo que dispõe sobre a matéria está ligado ao artigo que trata da Assembléia Legislativa".

${ }^{47}$ Art. 61. (...) \& 10 São de iniciativa privativa do Presidente da República as leis que: I - fixem ou modifiquem os efetivos das Forças Armadas; II - disponham sobre: a) criação de cargos, funções ou empregos públicos na administração direta e autárquica ou aumento de sua remuneração; b) organização administrativa e judiciária, matéria tributária e orçamentária, serviços públicos e pessoal da administração dos Territórios; c) servidores públicos da União e Territórios, seu regime jurídico, provimento de cargos, estabilidade e aposentadoria de civis, reforma e transferência de militares para a inatividade; d) organização do Ministério Público e da Defensoria Pública da União, bem como normas gerais para a organização do Ministério Público e da Defensoria Pública dos Estados, do Distrito Federal e dos Territórios; e) criação, estruturação e atribuições dos Ministérios e órgãos da administração pública. A jurisprudência sedimentada é de que as iniciativas reservadas são de absorção compulsória pelos Estados: "Processo legislativo dos Estadosmembros: absorção compulsória das linhas básicas do modelo constitucional federal entre elas, as decorrentes das normas de reserva de iniciativa das leis, dada a implicação com o princípio fundamental da separação e independência dos poderes: jurisprudência consolidada do Supremo Tribunal. " (BRASIL. Supremo Tribunal Federal. Ação Direta de Inconstitucionalidade no 637. Rel. Min. Sepúlveda Pertence. Julgado em 25.08.2004, DJ 01.10.2004).

${ }^{48}$ Confira-se, por exemplo, a Adin 1.060, MC, RDA 199/173, com menção à vários precedentes. Sobre a jurisprudência do STF em matéria de competências e suas implicações no desenho federativo, vejam-se os trabalhos de Thiago Magalhães Pires (2015) e Sérgio Ferrari (2008).
} 
que configuram restrições: i) a assinatura de cada eleitor deverá ser acompanhada de seu nome completo e legível, endereço e dados identificadores de seu título eleitoral, ii) as listas de assinatura serão organizadas por Município e por Estado, Território e Distrito Federal, em formulário padronizado pela Mesa da Câmara; iii) o projeto será instruído com documento hábil da Justiça Eleitoral quanto ao contingente de eleitores alistados em cada Unidade da Federação, aceitando-se, para esse fim, os dados referentes ao ano anterior, se não disponíveis outros mais recentes; iii) o projeto será protocolizado perante a Secretaria-Geral da Mesa, que verificará se foram cumpridas as exigências constitucionais para sua apresentação. Outros pontos importantes são contemplados no regimento: i) "será lícito a entidade da sociedade civil patrocinar a apresentação de projeto de lei de iniciativa popular, responsabilizando-se inclusive pela coleta das assinaturas", ii) "o projeto de lei de iniciativa popular terá a mesma tramitação dos demais, integrando a numeração geral das proposições"; iii) "nas Comissões ou em Plenário, transformado em Comissão Geral, poderá usar da palavra para discutir o projeto de lei, pelo prazo de vinte minutos, o primeiro signatário, ou quem este tiver indicado quando da apresentação do projeto" e "iv) "não se rejeitará, liminarmente, projeto de lei de iniciativa popular por vícios de linguagem, lapsos ou imperfeições de técnica legislativa, incumbindo à Comissão de Constituição e Justiça e de Cidadania escoimá-lo dos vícios formais para sua regular tramitação". ${ }^{49}$

Passo a discutir, em blocos separados, os tipos de limitações ao uso do instituto e as possibilidades de modificação, a fim de incrementar o seu uso e promover seu potencial construtivo. As análises dividem-se quanto aos limites relativos ao objeto, à quantidade de assinaturas, aos critérios de apresentação e conferência das assinaturas, ao financiamento das campanhas de coleta e à fórmula de tramitação. Ao fim, trato das potencialidades e riscos da combinação da iniciativa popular com o referendo.

Quanto ao objeto da iniciativa popular, pode ser limitado de duas formas: fixando limites relativos à modalidade de norma jurídica que pode ter sua produção deflagrada pela iniciativa popular (leis ordinárias ou emendas constitucionais), ou pela restrição do escopo temático das propostas (como, por exemplo, matéria penal, direitos fundamentais, matéria tributária e orçamento $)^{50}$. No Brasil, não há limites relacionados ao conteúdo do projeto, mas apenas quanto à

\footnotetext{
49 Resolução no 17/1989, da Câmara dos Deputados (Regimento Interno), art. 252, com alterações efetivadas pela Resolução no 20/2004.

50 Não há como, nos estreitos limites desse artigo, explorar a discussão sobre a necessidade e as implicações da limitação temática do uso de ferramentas de democracia semidireta. Registre-se, apenas a título de
} 
modalidade normativa, pois não há previsão explícita quanto à iniciativa para emendas.

Apesar de a Constituição de 1988 não prever qualquer limite de caráter substantivo quanto às iniciativas populares, esse é um tema sensível que não pode ser menosprezado. Uma das principais implicações da ampliação dos mecanismos de democracia semidireta é a ameaça que representam para os direitos fundamentais, especialmente de minorias. Quanto mais facilitado seu manejo, mais acentuada a tensão entre democracia majoritária e direitos humanos. Nesse contexto, a ativação da participação direta, nos sistemas constitucionais entrincheiram direitos fundamentais, requer o estabelecimento de limites que impeçam que se firme um desequilíbrio em desfavor daqueles. Há múltiplos modelos de restrições das matérias passíveis de iniciativa em sistemas jurídicos estrangeiros. Na Argentina, por exemplo, a Constituição estabelece que "não serão objeto de iniciativa popular os projetos referentes a reforma constitucional, tratados internacionais, tributos, orçamento e matéria penal". Nos Estados Unidos, metade dos estados que preveem iniciativa popular contemplam restrições quanto ao conteúdo das proposições. Há impedimentos de variados tipos, como a vedação de proposições que interfiram com instituições religiosas, que criem cortes, estabeleçam leis individuais ou privadas, que determinem desapropriação, que criem monopólios e etc. (INITIATIVE \& REFERENDUM INSTITUTE, 2016) ${ }^{51}$. Essas previsões são ponto de partida para interessantes discussões sobre as fronteiras da democracia semidireta. No Brasil, um limite conveniente a fim de preservar as conquistas emancipatórias da Constituição 1988 e evitar uma sobrecarga das cortes seria vedar iniciativas debilitando ou restringindo direitos e garantias individuais, especialmente em matéria penal. Na minha visão, esses dois freios seriam necessários para conciliar a proteção da autonomia individual com um incremento da eficiência da democracia semidireta. O estabelecimento de barreiras substantivas permite incentivar o uso da democracia semidireta sem aumentar os riscos que the são inerentes.

Quanto ao tipo de norma que pode ser objeto de iniciativas populares, num primeiro lance

exemplo, que a Constituição de Massachussets enumera diversas matérias que não podem constituir seu objeto, tais como direitos fundamentais, criação de tribunais, assuntos religiosos, assuntos de interesse local, etc. (Artigo 48, seção 2); a Constituição da Califórnia determina que as iniciativas não podem nomear indivíduos para ocupar um posto, ou identificar corporação privada para realizar qualquer função ou ter qualquer poder ou encargo (Artigo 2, seção 12); outros Estados - Massachusetts, Nebraska e Oklahoma estabelecem que as iniciativas constitucionais rejeitadas pelos eleitores não podem ser representadas antes de três anos; nenhum estado da federação, com exceção da Flórida, admite a iniciativa popular para revisão total da Constituição. Veja-se, sobre o tema, INITIATIVE \& REFERENDUM INSTITUTE, 2016.

51 As informações também foram consultadas no sítio eletrônico da Conferência Nacional de Legislaturas Estaduais. $\quad<$ http://www.ncsl.org/research/elections-and-campaigns/initiative-subject-restrictions.aspx>. Acesso em: 26 out. 2016. 
de vista, o sistema brasileiro admite seu uso apenas para leis ordinárias e complementares, sem previsão expressa de seu uso para deflagrar processo de emenda à constituição. Esse ponto, todavia, é controvertido e merece atenção.

No texto constitucional de 1988, o catálogo de órgãos e autoridades habilitados para apresentar proposta de mudança no texto constitucional é enumerado no artigo 60, que não faz referência à parcela do eleitorado ${ }^{52}$. Dessa forma, a interpretação a contrario sensu do dispositivo induz à leitura de que não é viável estendê-la a outros sujeitos além daqueles expressamente enumerados. Na década de noventa, quando houve ao processo de revisão simplificada, previsto no artigo 3o das disposições transitórias da Constituição de 1988, debateu-se a viabilidade de que fosse deflagrado mediante iniciativa popular, tendo em vista a circunstância de que o preceito não fez menção a os critérios de apresentação de propostas. Naquele contexto, Fábio Konder Comparato (1990) sustentou ser razoável que o processo de revisão constitucional previsto no artigo 3 do Ato das Disposições Constitucionais Transitórias pudesse "ser instaurado mediante proposta de qualquer das pessoas ou entidades anunciadas no artigo 61, como se tratasse de iniciativa em matéria de legislação complementar ou ordinária". Na prática, porém, isso não aconteceu. O processo de revisão não gerou mobilização, resultando em poucas alterações, que não provocaram mudanças substanciais e abrangentes na Constituição.

Esse argumento, porém, não é transponível ao processo de emenda $a^{53}$ da Constituição. Os critérios relativos à legitimação para propor emendas encontram-se diretamente regulados no artigo 60. A iniciativa popular, por seu turno, só é prevista e disciplinada na subseção relativa ao procedimento para formação de leis ordinárias e complementares. Dessa forma, numa leitura textual e preliminar, apenas mediante alteração no texto da Constituição poderá vir a ser admitida iniciativa popular para o fim de emendá-la. Mas há autores que, preconizando uma intepretação sistemática e orientada à promoção da soberania popular, defendem a possibilidade de iniciativa popular para emendas. José Afonso da Silva (2006a, p. 63) entende ser viável, com lastro em uma interpretação sistemática dos artigos constitucionais relativos à democracia e aos direitos políticos (art. 1o, parágrafo único, 14 e 61), que a iniciativa popular seja usada para deflagrar o processo de

52 Art. 60. A Constituição poderá ser emendada mediante proposta: I - de um terço, no mínimo, dos membros da Câmara dos Deputados ou do Senado Federal; II - do Presidente da República; III - de mais da metade das Assembléias Legislativas das unidades da Federação, manifestando-se, cada uma delas, pela maioria relativa de seus membros. (...)

53 Comparato (1990), assinala a ausência de distinção clara entre os termos emenda e reforma da Constituição, tanto na história constitucional brasileira como no direito comparado. Conclui, porém, que o art. 3o do ADCT inspirou-se, de forma deturpada, no artigo 286 da Constituição Portuguesa de 1976, o qual prevê um poder de revisão permanente para a Assembleia, de cinco em cinco anos. 
emenda à Constituição. Destaca, porém, que isso seria admissível se a lei que regulamentou a iniciativa popular "tivesse disposto nesse sentido" (SILVA, 2006b, p. 310). Sua leitura, portanto, parece ser no sentido de de que a constituição não exclui essa possibilidade, que poderia ter sido prevista na lei ordinária que trata do assunto. Já Fábio Konder Comparato, de forma mais radical, entende que iniciativas populares não podem ser recusadas pela inferência de que seriam vedadas nos casos não previstos no texto constitucional, pois isso corresponderia a colocar os "mecanismos de democracia direta em posição hierarquicamente inferior à representação popular" 54 .

A questão não é simples, pois, ainda que uma interpretação textual e ortodoxa conduza à conclusão de que não são cabíveis iniciativas para mudar a Constituição, um cenário de ampla mobilização e pressão popular poderia produzir uma mutação constitucional que resultasse na admissão do uso desses instrumentos como mecanismo de preservação da própria Constituição de 1988. Em cenários de crise, a iniciativa popular pode servir como canal de propagação da energia democrática, evitando rupturas que resultem na manifestação de um novo poder constituinte. Por isso mesmo, é recomendável que o texto constitucional seja alterado para contemplar a possibilidade de apresentação de propostas de emendas à constituição por iniciativa popular. Já tramitaram várias propostas de emenda constitucional nesse sentido, mas nenhuma delas avançou. Uma chegou a receber um parecer no sentido de sua inconstitucionalidade, por entender o relator que haveria violação aos limites implícitos de poder de reforma ${ }^{55}$. Essa tese não me

54 "[A]inda que se considere que as manifestações diretas da soberania popular estão em nível igual e não superior ao exercício dessa soberania por intermédio de representantes, não se pode negar que a equipolência constitucional de ambas impede se considerem admissíveis o referendo, o plebiscito e a iniciativa popular, unicamente quando previstos de modo expresso e pontual no texto da Constituição" (COMPARATO, 1994).

${ }^{55}$ A PEC no 30/2009 visava acrescentar o inciso IV ao art. 60 da Constituição Federal para incluir o eleitorado, mediante iniciativa popular, no rol dos legitimados para apresentar proposta de emenda à Constituição. $\mathrm{A}$ PEC recebeu parecer desfavorável, de relatoria do Senador Marco Maciel, que afirmou que a Constituição objetiva ter "certo grau de perenidade, evitando dessa forma mudanças inconsequentes, movidas por paixões ou interesses ocasionais". Por isso, seria exigida maioria qualificada para aprovação de proposta de emenda à Constituição e a assinatura de determinado número de congressistas para sua deflagração. A apresentação de PEC por iniciativa popular levaria a um risco de banalização de propostas e entrave do processo legislativo no Congresso Nacional. $O$ parecer pode ser consultado em: $<$ http://legis.senado.leg.br/mateweb/arquivos/mate-pdf/83401.pdf>. Acesso em: 27 out. 2016.

Note, contudo, que foi determinada a tramitação conjunta da PEC no 30/2009 com a PEC no 3/2011, já apensada à PEC no 45/2011. No sentido da PEC no 30/2009, a PEC no 3/2011 busca acrescentar o inciso IV ao caput do art. 60 e o § 3o ao art. 61 da Constituição, e altera a redação do $\S 2$ 2o também do art. 61, para viabilizar a apresentação de propostas de emenda à Constituição de iniciativa popular e facilitar a apresentação e a apreciação de projetos de lei respectivos. A PEC foi aprovada em primeiro turno no plenário do Senado Federal e encontra-se, atualmente, na Câmara dos Deputados, onde aguarda parecer do relator na Comissão de Constituição e Justiça e de Cidadania (CCJC). Em virtude da aprovação em primeiro turno da PEC no 3/2011, foi declarada a prejudicialidade da PEC no 45/2011 e da PEC no 30/2009. 
parece acertada. A teoria dos limites implícitos ao poder de reforma tem por fundamento a distinção entre o emissor e o receptor do poder de mudar a Constituição (SAMPAIO, 1995; FERRAZ JUNIOR apud MIRANDA, 2013, p. 90-91), ou seja, entre o titular do poder constituinte e o titular do poder de reforma. Uma alteração no catálogo de legitimados para propor mudanças constitucionais que confira à parcela dos cidadãos o poder de apresentar propostas de mudança não altera a titularidade do poder reformador. Bem ao contrário, entendo que uma alteração desse preceito para pluralizar o catálogo de proponentes poderia dar mais força e vitalidade à Constituição, contribuindo para sua preservação. Essa ideia não significa acolher a chamada tese da dupla revisãa $0^{56}$ - ou da reforma em dois tempos -, segundo a qual os critérios formais de mudança constitucional podem ser modificados, desde que observadas, na primeira etapa, as regras estabelecidas pelo poder constituinte originário. Trata-se, diversamente, de sustentar que ainda que se reconheça a existência de limites formais implícitos ao poder de reforma, a ampliação dos titulares do poder de iniciativa não viola tais limites, pois, de um lado, não promove uma mudança na instância decisória final e, de outro lado, coopera para a preservação do pacto constitucional, não para o seu desgaste.

É passível de discussão, também, a possibilidade de as constituições estaduais e leis orgânicas dos municípios preverem a possibilidade de iniciativa popular para emendar o seu próprio texto. Quanto à questão da viabilidade de a iniciativa popular ser empregada para emenda a constituições estaduais, suscita um problema interpretativo. Poder-se-ia argumentar que, como prevalece o entendimento de que as regras constitucionais básicas atinentes ao processo legislativo se projetam nos Estados - cujos ordenamentos devem, quanto a este tema, com elas guardar simetria - a inexistência de previsão constitucional de iniciativa popular para reforma de seu texto teria que ser repetida pelas cartas estaduais. Nessa ordem de ideias, a iniciativa popular nessa esfera encontraria os mesmos limites materiais estabelecidos na Constituição Federal, não podendo ser utilizada para reforma das cartas estaduais. A questão reside, assim, em saber se a norma relativa à titularidade para propor emenda ao texto constitucional constitui princípio básico do processo legislativo e, consequentemente, em delinear a amplitude da moldura constitucional

\footnotetext{
${ }^{56}$ Não é dado ao poder constituinte derivado alterar o processo de emenda da constituição, que seria um limite implícito ao poder reformador. Em Portugal, porém, surgiu a discussão relativa à tese da dupla revisão. Entre as décadas de 80 e 90, a constituição portuguesa precisaria passar por uma série de mudanças para permitir o ingresso de Portugal na Comunidade Europeia. A tese da dupla revisão, assim, preconizava que o poder reformador poderia alterar os limites a ele impostos se o fizesse em duas etapas: admitiria a alteração ou eliminação de um limite material e, posteriormente, votaria a emenda que, em outra oportunidade, violaria o limite alterado. À época, Jorge Miranda (2013) acatou a tese, ao passo que Canotilho (1998) a rejeitou.
} 
que estabelece limitações implícitas à autonomia regulamentar dos Estados quanto a esse tema.

De fato, a norma que determina os titulares do poder de iniciativa para emenda à Constituição Federal não pode, de forma razoável, ser considerada como elementar para fins de aplicação simétrica aos Estados, dado que não é corolário de nenhum princípio elementar da organização federal. Na solução de problemas interpretativos dessa ordem, cabe recorrer aos princípios constitucionais gerais relativos ao exercício do poder político. Assim, essa leitura, além de não ser incompatível com os princípios gerais relativos ao exercício do poder político consagrados no texto constitucional, incrementa a realização normativa do princípio da soberania popular enunciado no artigo 1으 da Carta de 1988. A confirmar esses argumentos está o fato de que diversos Estados da federação contemplaram a iniciativa popular para emendas a suas constituições, a saber: Acre ${ }^{57}$, Alagoas ${ }^{58}$, Amapá ${ }^{59}$, Amazonas $^{60}$, Espírito Santo ${ }^{61}$, Goiás ${ }^{62}$, Pará ${ }^{63}$, Pernambuco ${ }^{64}$, Rio Grande do Sul ${ }^{65}$, São Paulo ${ }^{66}$, Santa Catarina ${ }^{67}$ e Sergipe ${ }^{68}$. Vale destacar que o dispositivo que prevê a iniciativa popular para emenda à Constituição do Amapá foi objeto de Ação Direta de Inconstitucionalidade, e o Supremo Tribunal, neste caso, indeferiu a Medida Cautelar requerida no que tange àquela iniciativa ${ }^{69}$.

No que tange à possibilidade de as leis orgânicas municipais estabelecerem a iniciativa popular para emenda de seus textos, aplicam-se os mesmos argumentos já tratados quanto aos Estados. Assim, a obrigatoriedade de os municípios observarem os princípios do processo legislativo federal também não impede a adoção da iniciativa popular para emendas à lei orgânica ${ }^{70} / 71$. Mas há ainda outro aspecto a ser considerado quanto a essa questão. É que, no que

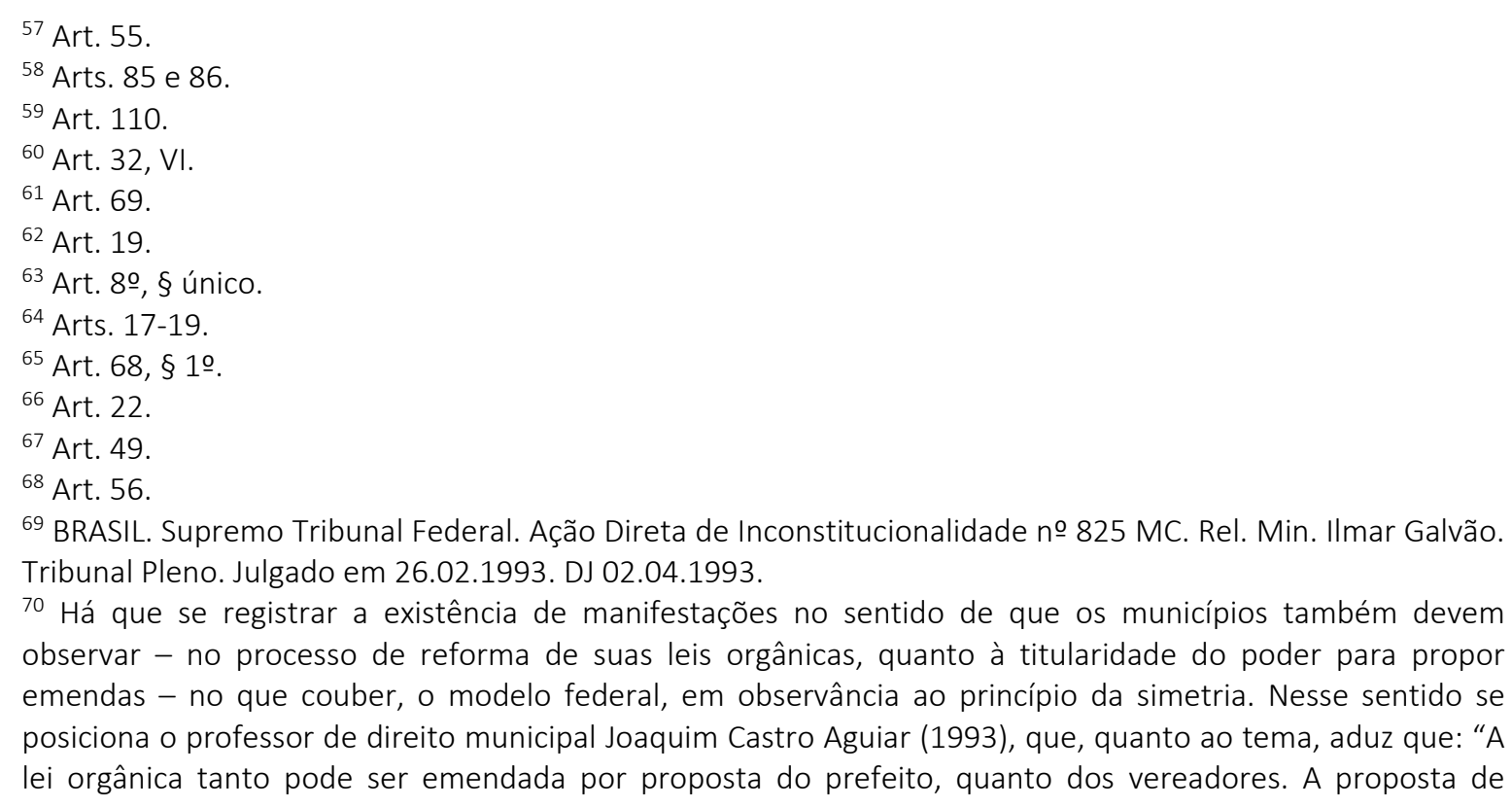


se refere aos municípios, o tratamento constitucional é diverso do dispensado aos estados. 0 dispositivo da Carta de 1988 que prevê a iniciativa popular para normas municipais refere-se explicitamente a "projetos de lei". Porém, não parece razoável supor que pelo fato de o dispositivo mencionar "lei" restaria excluída possibilidade de se estabelecer iniciativa popular para emendas à lei orgânica. A propósito, cumpre registrar que as leis orgânicas dos municípios de São Paulo ${ }^{72}$ e Rio de Janeiro ${ }^{73}$ autorizam a utilização da iniciativa popular para emendas a seus textos.

Quanto aos municípios existe, ainda, outra restrição de ordem substancial. O texto constitucional refere-se à iniciativa popular para projetos de "lei de interesse específico do Município, da cidade ou de bairros". Nessas circunstâncias, como bem observa Castro Aguiar (1993, p. 94), "se houver, por exemplo, interesse que afete região metropolitana, que envolva Municípios limítrofes, já não há interesse específico dos Municípios, de suas cidades ou de bairros.". O objetivo, ao que tudo indica, é adequar a iniciativa ao critério de distribuição de competências ancorado na predominância do interesse e evitar conflitos entre as unidades territoriais.

No que se refere às condições para o exercício da iniciativa popular, outros três pontos devem ser examinados: a questão relativa ao número de assinaturas exigidas, à forma de apresentação do projeto e aos critérios de conferência da validade das assinaturas.

O número ideal de adesões necessárias a deflagração de uma iniciativa popular constitui objeto de divergências. Em geral, é dado destaque ao fato de que se afigura recomendável que o patamar exigido estabeleça um equilíbrio, não constituindo um fator de desestímulo à utilização do instituto nem tampouco implicando sua vulgarização. A Constituição de 1988, como se viu, ao fixar o número de assinaturas necessário ao exercício da iniciativa popular na esfera federal, determinou que o projeto seja subscrito por no mínimo 1\% do eleitorado, distribuído em pelo menos cinco Estados da federação, com a adesão de pelo menos 0,3\% do eleitorado em cada um deles $^{74}$.

emenda dos vereadores só será aceita, se assinada por, no mínimo, um terço dos membros da Câmara. Estas conclusões resultam do fato de que os princípios do processo legislativo têm aplicação aos Municípios".

${ }^{71}$ Apesar das críticas de renomados constitucionalistas, como, v. g., José Afonso da Silva (1985, p. 408), não há mais dúvida que os municípios integram a federação, em face do disposto nos artigos 1 o e 18 da Constituição de 1988.

${ }^{72}$ Art. 5, § 1 , II.

${ }_{73}$ Art. 67, I.

$74 \mathrm{O}$ fato de o constituinte ter fixado o patamar de assinaturas em termos percentuais permite que a dificuldade/facilidade para as obter seja proporcionalmente mantida, impedindo que se opere uma defasagem em relação ao momento da promulgação do texto, a exemplo o que ocorre nos países em que a 
A quantidade elevada de assinaturas exigida pela Carta é considerada por muitos um elemento que torna praticamente inviável a utilização da iniciativa popular, traduzindo provavelmente a intenção do constituinte de evitar sua utilização. Manoel Gonçalves Ferreira Filho (1995, p. 202), por exemplo, afirma ser instituto meramente decorativo, tendo em vista o rigor das exigências constitucionais estabelecidas para sua apresentação. No campo da ciência política, José Álvaro Moisés (1990, p. 86) chamou atenção para o fato de que, tomando como paradigma a experiência do período constituinte, quando apenas os setores mais bem articulados da sociedade lograram participar do processo, seria possível fazer uma previsão pessimista da aplicação da iniciativa popular federal nos moldes previstos na constituição. A previsão do autor se concretizou. Dos projetos de iniciativa popular, apenas quatro viraram leis ${ }^{75}$, sendo que tais projetos, durante a sua tramitação, foram assumidos por parlamentares, a fim de facilitar seu andamento ${ }^{76}$. Como

exigência é fixada em números absolutos. Na Suíça, o número de 50.000 assinaturas fixado na Constituição de 1892 foi atualizado apenas em 1977, quando passou para 100.000. Na Itália, a necessidade de 50.000 assinaturas representa hoje apenas $0,1 \%$ do eleitorado.

75 No Congresso, apenas quatro projetos de iniciativa popular tornaram-se leis, como bem expõe Ricardo Mendes Cardoso (2010, p. 108-119): (i) o PL no 2.710/92 foi convertido na Lei no 11.124/05, a qual dispõe sobre o Sistema Nacional de Habitação de Interesse Social (SNHIS), cria o Fundo Nacional de Habitação de Interesse Social (FNHIS) e institui o Conselho Gestor do FNHIS. Contudo, por não ter sido comprovado o preenchimento dos requisitos constitucionais para recebimento da proposta de iniciativa popular, foi assumido pelo Parlamentar Nilmário Miranda (PT); (ii) o Projeto Daniela Perez ou Projeto Glória Perez (PL no 4.146/93) foi convertido na Lei no 8.930/94, a qual inclui o homicídio qualificado no rol dos crimes hediondos. Note que a proposta foi adotada pelo Poder Executivo, o que, além de permitir a regular tramitação no Congresso Nacional, evitou a necessária avaliação da presença dos requisitos constitucionais para apresentação de proposta de iniciativa popular; (iii) o PL no 1.517/99 foi aposto pela assinatura de 60 parlamentares, evitando a necessária avaliação dos requisitos constitucionais da iniciativa popular. O PL foi convertido na Lei no 9.840/99, que, visando combater a corrupção eleitoral, tipificou o crime de compra de votos; (iv) o PLP no 518/09, após ter sido assumido por um grupo de parlamentares com o intuito de acelerar a tramitação e permitir que a lei, se aprovada, fosse aplicada nas eleições de 2010, foi prejudicado em razão de substitutivo (PLP no 168/93), o qual originou a Lei da Ficha Limpa (Lei Complementar no 135/10). Esta lei inclui na legislação eleitoral sobre casos de inelegibilidade, prazos de cessação e outras providências, hipóteses de inelegibilidade que visam a proteger a probidade administrativa e a moralidade no exercício do mandato.

76 Cabe, aqui, mencionar as 10 Medidas Contra a Corrupção elaboradas pelo Ministério Público Federal. Em 2014, membros do MPF integrantes da Força-tarefa da Lava Jato em Curitiba (PR), com o intuito de combater a corrupção e a impunidade, começaram a desenvolver propostas de alterações legislativas. Em janeiro de 2015, o Procurador Geral da República, Rodrigo Janot, criou comissões de trabalho para aprimorar as propostas. Em março do mesmo ano, o MPF lançou, a nível nacional, a campanha 10 Medidas Contra a Corrupção. O MPF passou a coletar assinaturas de cidadãos que apoiavam as medidas em todo o Brasil. Em fevereiro de 2016, o projeto alcançou 1,5 milhão de assinaturas, quantidade necessária para que as medidas fossem apresentadas como projeto de lei de iniciativa popular no Congresso. Em março, quando o projeto contava com mais de 2 milhões de assinaturas, Parlamentares da Frente Mista de Combate à Corrupção apresentaram o PL 4850/2016 na Câmara dos Deputados. O PL, que abrange integralmente as propostas do MPF, estabelece medidas contra a corrupção e demais crimes contra o patrimônio público e combate o enriquecimento ilícito de agentes público. No momento em que este artigo foi escrito, o projeto estava em tramitação na Câmara dos Deputados e aguardava a instalação de Comissão Temporária e o parecer do 
destacou Francisco Whitaker (2003) a experiência recente ensejou "a descoberta de uma verdadeira armadilha para os projetos de lei de iniciativa popular: eles não podem tramitar como tais, mas somente como projetos de iniciativa parlamentar..." ${ }^{\prime 77}$. Todavia, vale ponderar que, apesar desses entraves, a função da iniciativa popular de promover a deliberação social e legislativa sobre o assunto foi cumprida em algum grau.

De qualquer forma, o maior obstáculo não reside no número de assinaturas requerido, mas no requisito de ordem geográfica traduzido na exigência de que estas estejam distribuídas em pelo menos cinco Estados, com adesão de, no mínimo, 0,3\% do eleitorado de cada um deles, bem como na forma burocratizada de conferência das assinaturas. Apesar de o percentual determinado quanto aos Estados ser relativamente baixo, a imposição de que sejam coletadas assinaturas em diversos lugares diferentes aumenta sobremaneira a dificuldade e, consequentemente, o volume de recursos financeiros necessário para empreender a campanha de formalização da iniciativa popular.

É verdade que esta dificuldade é amortecida pela ausência de prazo para coleta das assinaturas. Na Suíça, por exemplo, após o depósito da iniciativa os proponentes dispõem de dezoito meses para recolher as firmas ${ }^{78}$. Essa exigência existe também em vários Estados da federação norte-americana, com prazos diversos. A ausência de limite de tempo para o recolhimento das assinaturas, porém, pode ter o efeito de implicar a perda de interesse da sociedade na questão objeto da iniciativa. Em termos objetivos, e comparada com a experiência internacional, a exigência de assinatura de $1 \%$ do eleitorado não é exorbitante. Portanto, a diminuição do percentual pode ser desejável a fim de ampliar a participação popular no processo legislativo, mas provavelmente não constitui a barreira mais importante. A demanda de

Relator da Comissão Especial. Há dois aspectos problemáticos nesse projeto. Primeiro, o fato de ter sido capitaneado por agentes públicos que terão incremento de poder e de relevância institucional com a sua aprovação, e que inclusive usaram, na campanha de captação de assinaturas, o próprio aparato institucional, fator que enseja uma reflexão sobre conflito de interesses nos projetos de iniciativa popular que envolvem poderes de agentes públicos. Segundo, a circunstância de que o projeto envolve uma releitura do direito penal e o enfraquecimento de garantias constitucionais, elemento que tem se apresentado, nas experiências internacionais, como um dos mais problemáticos no que se refere à tensão entre o uso de instrumentos de democracia direta e direitos individuais.

${ }^{77}$ E acrescenta: "Ou seja, na prática, estamos condenados a fazer um vasto esforço para colher o enorme número de assinaturas necessárias e a entregar em seguida o projeto a um de nossos representantes no Congresso para que o apresente como seu autor. Isso significa que, de fato, não existe a iniciativa popular de lei no Brasil, apesar das aparências e de todo o nosso entusiasmo quando conquistamos a aprovação, na Constituinte, desse "poderoso" instrumento de participação popular." (WHITAKER, 2003, p. 189-190).

$78 \mathrm{O}$ procedimento de revisão constitucional total encontra-se disciplinado pelo artigo 120 da Constituição Suíça, que estabelece que este pode ser iniciado mediante proposta amparada por assinaturas de 100.000 eleitores, e tais recolhidas dentro de um período de dezoito meses. 
distribuição territorial, todavia, cria um entrave relevante tanto para o custo e operacionalidade da coleta como para a posterior aferição do cumprimento do requisito. Inviabiliza, ainda, a possibilidade de a iniciativa ser manejada quanto a assuntos que possam ter impacto severo em localidades determinadas, mas que envolvam competência legislativa privativa da União. Pense-se, por exemplo, em questões relativas aos requisitos de implantação de instalações nucleares ${ }^{79}$, que são de competência da União, mas podem gerar mobilização apenas nos locais onde as usinas são estabelecidas. A eliminação da exigência, por si só, diminuiria o custo do processo de captação das assinaturas e facilitaria a aplicação do instituto. Uma fórmula possível, que poderia incrementar o uso da iniciativa popular, seria manter a regra da distribuição territorial em vários estados apenas para a apresentação de propostas de emendas à Constituição, deixando para as iniciativas de lei apenas o requisito percentual. Seria mantida, assim, uma distinção de dificuldade de deflagrar o processo de emenda das leis, que deflui logicamente do modelo de constituição rígida ${ }^{80}$. A redução do percentual para leis ordinárias também é desejável. Uma solução possível seria reduzir para 0,5\% do eleitorado. Outra, estabelecer que o percentual incida não sobre a quantidade de eleitores inscritos, mas sobre o número de eleitores que efetivamente tenha votado nas eleições imediatamente anteriores ao momento em que se inicia a coleta de assinaturas.

No âmbito estadual, como já mencionado, a Constituição não prescreveu qualquer requisito, deixando ao legislador liberdade regulamentar para estabelecer as condições de ordem formal e substancial da iniciativa. Uma vez que os limites impostos pelo princípio da simetria referem-se apenas aos delineamentos básicos do procedimento legislativo, não há qualquer óbice a que os Estados fixem o número mínimo de assinaturas exigidos para iniciativa popular em patamar diverso daquele estabelecido no âmbito federal. Assim, cartas estaduais fixaram

\footnotetext{
${ }^{79}$ Na ADI 329, o MPF questionou a constitucionalidade do art. 185 da Constituição do estado de Santa Catarina, que prevê que a implantação de instalações industriais para produção de energia nuclear no estado depende, além do atendimento às condições ambientais e urbanísticas exigidas em lei, de autorização prévia da Assembleia Legislativa, ratificada por plebiscito feito pela população eleitoral catarinense. Em 2004 e em decisão unânime, o STF julgou o pedido procedente, pois o tema tratado no dispositivo da constituição estadual seria de competência privativa da União Federal para legislar sobre atividades nucleares de qualquer natureza, ainda que os estados possam legislar de forma supletiva quando haja autorização em lei complementar. (BRASIL. Supremo Tribunal Federal. Ação Direta de Inconstitucionalidade no 329. Relatora Ministra Ellen Gracie, julgamento em 01.04.2004, DJ 28.05.2004).

${ }^{80}$ A Proposta de Emenda à Constituição no 286/2013 visa a alterar os arts. 60 e 61 da Constituição Federal para facilitar o uso da iniciativa legislativa. A PEC diminui o número de assinaturas necessárias para a apresentação de projetos de lei de iniciativa popular para 0,5\%, pelo menos, cinco estados, com não menos de $0,1 \%$ dos eleitores de cada um deles. No caso das propostas de emenda à Constituição de iniciativa popular, a exigência vai ser a adesão de $1 \%$ do eleitorado, também distribuído por cinco estados, com pelo menos de $0,3 \%$ dos eleitores de cada um deles.
} 
diferentes exigências para o exercício do direito de iniciativa popular. O Estado do Amazonas, por exemplo, fixou o percentual de adesão de $5 \%$ do eleitorado para iniciativa de emenda à constituição, distribuído por vinte e cinco municípios, com um mínimo de $5 \%$ de cada município. Trata-se do patamar mais elevado da federação. O Estado da Bahia, por outro lado, estabeleceu a exigência numérica de $1 \%$, para emendas, e de 0,5 \% para leis, sem necessidade de estarem recolhidas em determinado número de municípios. Em Minas Gerais, onde é admitida apenas a iniciativa legislativa, são exigidas 10.000 assinaturas, sendo que no máximo vinte e cinco por cento das assinaturas poderão ser de eleitores alistados na Capital do Estado. O índice mais baixo da federação para emendas constitucionais estaduais é aquele estabelecido na Constituição do Pará, de $0,5 \%$ dos eleitores distribuídos por, no mínimo, dez municípios, com 0,3\% de eleitores de cada um deles. Um dos índices mais baixos para projetos de lei é o fixado pela Carta do Rio de Janeiro, de $0,2 \%$ do eleitorado, distribuídos em pelo menos dez municípios com não menos de $0,1 \%$ em cada um deles. Todavia, um limitador importante ao uso da ferramenta na esfera estadual é a circunstâncias de as competências legislativas dos Estados não terem grande proeminência, seja em decorrência do desenho constitucional que as colocou comprimidas entre as abrangentes competências da União e as competências municipais, seja em virtude da jurisprudência do STF que, lastreada na construção do princípio da simetria, diminuiu drasticamente a flexibilidade e a criatividade constituinte no plano estadual.

De outra parte, como já mencionado, a Constituição fixou o percentual de 5\% para a iniciativa popular de leis municipais. Neste caso, trata-se de patamar efetivamente alto, e é lamentável que se tenha estabelecido obstáculo desta ordem justamente onde o instituto poderia funcionar de forma mais eficaz: no âmbito local. De fato, é a esfera municipal o ambiente ideal para o funcionamento da iniciativa popular. Diversos fatores contribuem para este quadro, dentre os quais pode-se destacar: i) a maior facilidade para coletar assinaturas decorrente do menor espaço territorial; ii) a maior probabilidade de engajamento dos cidadãos em questões que digam respeito ao seu cotidiano, como em geral ocorre com os assuntos de interesse local; iii) a proximidade dos cidadãos subscritores da iniciativa das autoridades que irão votá-la. Pesquisas no campo da ciência política indicam que há uma correlação direta entre o coeficiente de assinaturas exigido e a intensidade de seu uso ${ }^{81}$. Entretanto, não é possível traçar de antemão um percentual

\footnotetext{
${ }^{81}$ Confira-se o estudo de ARNOLD; FREIER, 2013 sobre a Bavária, em que se conclui que "uma queda no número de assinaturas exigidas faz aumentar significativamente a probabilidade de uma iniciativa. Embora a probabilidade de linha de base para observar uma iniciativa num Município seja cerca de 15\% em determinado ano, o requisito de assinatura mais baixo aumenta essa probabilidade em 8-10 pontos
} 
ótimo, pois é intuitivo que outros fatores têm potencial para interferir com a mobilização democrática, tais como o grau de igualdade econômica da comunidade, o estabelecimento de organizações sociais e de uma cultura de ativismo político, a quantidade de demandas ignoradas pelas instâncias de representação, a disponibilidade de recursos para financiar a coleta de assinaturas e etc. Por isso, a avaliação dos efeitos das normas vigentes é um fator apto a demonstrar, empiricamente, se o índice previsto é apto desencadear uma utilização deficitária, ótima ou excessiva do instituto. No caso dos municípios brasileiros, há sinais de que é necessário debater a redução do coeficiente estabelecido no texto constitucional. A título de exemplo, um breve levantamento no município do Rio de Janeiro indica que não há em tramitação nenhum projeto de iniciativa popular, nem houve há registro de algum recente ou de lei municipal aprovada por essa via ${ }^{82}$.

Quanto aos aspectos de forma, a iniciativa popular pode, teoricamente, ser apresentada em dois formatos: por meio de uma proposta formulada em termos gerais ou de um projeto redigido de forma articulada, e, portanto, pronto para ser submetido ao exame do Legislativo. A Constituição de 1988, pelo que se depreende dos termos do artigo 61, II, prevê exclusivamente a iniciativa popular articulada para o processo legislativo federal. A Lei 9.709/98, ao regular o instituto, confirmou a previsão constitucional ao mencionar que a iniciativa deve ser apresentada por meio de um projeto. A exigência de apresentação de um projeto articulado, todavia, não deve representar fundamento para a recusa de projetos. Tanto a lei como o regimento determinam a retificação dos vícios formais na casa legislativa, contemplando até mesmo a cisão em dois projetos no caso de não observância do requisito de unidade temática. Paralelamente, as constituições estaduais e leis orgânicas municipais podem, pelas razões já enumeradas, contemplar fórmulas distintas da adotada no modelo federal.

Ainda no que se refere às condições formais, cumpre observar que a Lei 9.709/98 não contém qualquer previsão quanto ao controle de autenticidade das assinaturas. O Regimento, como já tratado, enuncia requisitos burocráticos, como o preenchimento de formulário padronizado e a instrução com documentos da Justiça Eleitoral que comprovem o contingente de

percentuais. Os efeitos devem, portanto, ser vistos como imensos.".

82 Entramos em contato com os gabinetes de alguns vereadores da Câmara Municipal do Rio de Janeiro, quais sejam, Renato Cinco (PSOL), Brizola Neto (PSOL) e Jorge Felippe (PMDB), os quais, segundo o setor de comunicação social da Câmara, teriam o perfil mais próximo de encabeçar projetos de iniciativa popular. Todos, porém, informaram que não há projetos com esta origem. A Diretoria de Processamento Legislativo, por sua vez, foi enfática ao afirmar que não há nenhum projeto de iniciativa popular tramitando e nem houve recentemente.

Revista de Direito da Cidade, vol. 08, no 4. ISSN 2317-7721 pp. 1707- $1756 \quad 1744$ 
eleitores alistados. Além disso, autoriza que entidade da sociedade civil patrocine a apresentação de projeto de lei de iniciativa popular, responsabilizando-se pela coleta das assinaturas. Em sentido semelhante, a Constituição do Estado de Minas Gerais prevê, em seu artigo 67, que a lista deve ser organizada por entidade associativa legalmente constituída, que se responsabilizará pela idoneidade das assinaturas, a exemplo do que foi feito à época da constituinte quanto às emendas populares. É uma fórmula interessante, pois, de um lado, desburocratiza o processo de conferência e controle da validade, e, de outro, é mais sindicável do que o modelo de mera conferência por amostragem, adotado em alguns estados norte-americanos.

Quanto ao tópico da apresentação e conferência das assinaturas, entra em cena a questão da democracia digital. Há ainda um descompasso entre a agilidade das comunicações digitais contemporâneas e as fórmulas de participação dos cidadãos de produção de normas, especialmente no que se refere à iniciativa popular, que, na esfera federal, ainda precisa ser feita por meio de documentos em papel. Há projeto em tramitação no Congresso Nacional que visa a alterar da Lei 9.709/98, a fim de permitir que as assinaturas sejam coletadas, também, por meio de assinatura digital "devidamente certificada" ${ }^{83}$. Estima-se que a possibilidade de coletar assinaturas digitais possa facilitar o processo e ampliar a participação. Não se deve perder de vista, porém, que o Brasil é um país desigual com um índice intermediário de inclusão digital, e que a certificação digital, mesmo nos grandes centros, não é amplamente difundida (GOMES, 2016). Em vista desses fatores, parece mais interessante e inclusivo o modelo adotado no Estado de Santa Catarina, no qual a Lei 16.585/2015 estabelece que "a subscrição de proposição de iniciativa popular poderá ser feita por meio eletrônico com a certificação de autenticidade da assinatura digital do eleitor ou, na impossibilidade de fornecimento gratuito dos meios de certificação digital a toda a população do Estado, mediante a inserção de dados do eleitor em cadastro específico, mantido em meio eletrônico e administrado pela Assembleia Legislativa do Estado de Santa Catarina (ALESC)"84. O cadastramento dos eleitores pela própria casa legislativa pode ser uma alternativa eficaz em comparação à exigência de obtenção de certificado digital.

Outros dois pontos relevantes são a questão do financiamento e da fórmula de tramitação.

83 O PL no 2024/2011 prevê a inclusão do seguinte parágrafo na Lei 9708/99 “§ 3o Os projetos de lei de iniciativa popular podem ser parciais ou totalmente subscritos por meio de assinatura digital devidamente certificada.". Já o PL no Lei 7005/2013 prevê, além da assinatura digital, que os projetos de iniciativa popular que não alcançarem o número mínimo de assinaturas tramitarão na forma de sugestões legislativas.

84 Trata-se da Lei no 16.585/2015, que pode ser consultada em <http://leisestaduais.com.br/sc/lei-ordinarian-16585-2015-santa-catarina-disciplina-a-iniciativa-popular-de-leis-a-que-se-refere-o-1-do-art-50-daconstituicao-estadual>. Acesso em: 26 out. 2016. 
A política tem um preço, que não é módico. Não há, no Brasil, normas disciplinando o financiamento de campanhas para coleta de assinaturas de iniciativa popular. Esse é um debate necessário, pois o volume de recursos aportado pode fazer com que determinadas pautas sejam capturadas por grupos poderosos e elites econômicas, de maneira que subverta os propósitos de pluralização do acesso à política que os mecanismos de democracia semidireta visam a promover. Uma fórmula interessante e não cerceadora da participação seria a criação de regras que conferissem transparência às campanhas e impedissem limitassem as doações por empresas. Na verdade, as questões relacionadas ao financiamento de campanhas e a influência do poder econômico nas campanhas envolvendo os mecanismos de democracia semidireta são tão complexas quanto as que envolvem a eleição de representantes. Não se pode, assim, ter uma visão idealizada da mobilização popular e supor que, nessa seara, não são necessários mecanismos de fiscalização e controle para garantir a integridade do processo democrático. Não é possível explorá-las nos estreitos limites deste artigo. Todavia, é importante ter em conta que a influência do dinheiro não deve ser negligenciada e merece atenção equivalente à dada ao financiamento e abuso do poder econômico processo eleitoral como um todo.

Quanto à fórmula de tramitação, não há previsão de tramitação especial para os projetos oriundos de iniciativas populares. Considerando o grau de mobilização necessário para que uma iniciativa seja apresentada, parece recomendável, à luz do princípio democrático, que algum procedimento de preferência ou urgência e tramitação simplificada fosse implementado.

Outro ponto relevante é o controle pelos tribunais. Nos sistemas constitucionais que adotam o controle de constitucionalidade, como Estados Unidos, Espanha e Itália, há a possibilidade de as leis aprovadas mediante iniciativa popular serem invalidadas. A combinação de judicial review e democracia direta estabelece uma nova fronteira de tensão entre autodeterminação popular e constitucionalismo de direitos, e representa uma dimensão singular da mecânica dos freios e contrapesos. O caso do casamento gay na Califórnia é um exemplo emblemático do confronto que pode ser estabelecido entre o povo e os tribunais. As cortes estaduais haviam declarado a inconstitucionalidade de leis ordinárias que baniram o casamento entre pessoas no mesmo sexo, o que deflagrou o movimento de colheita de assinaturas para a aprovação de uma emenda à Constituição estadual, que, mais tarde, veio a ser declarada inconstitucional pela Suprema Corte dos Estados Unidos (ROSENFELD; SAJÓ, 2012, p. 525). De acordo com Kenneth Miller (2009, p. 155), em amplo estudo sobre a atuação do controle das cortes sobre o conteúdo das decisões tomadas pela via da participação direta, em alguns estados 
norte-americanos as iniciativas populares estabeleceram um sistema híbrido de "constitucionalismo popular" e supremacia judicial, esvaziando os poderes dos Parlamentos e do Executivo. Este autor afirma que tanto os poderes das cortes como dos cidadãos deveriam ser moderados por reformas, embora os juízes de um modo geral tenham, recentemente, evitado que as maiorias avancem desproporcionalmente sobre os direitos civis das minorias. De fato, a existência de tribunais com poderes contramajoritários ameniza os inconvenientes da democracia direta, razão por que é legítimo supor que, no Brasil, reformas que promovessem a facilitação de seu uso pudessem encontrar, nas Cortes, uma barreira de contenção de seus potenciais riscos. ideal, como mencionei antes, é que o controle judicial seja conjugado com limitações substantivas que impeçam o uso de iniciativas populares com o escopo de restringir direitos fundamentais ou que visem a subtrair direitos de minorias ${ }^{85}$.

Por fim, um dos aspectos mais problemáticos, que merece especial atenção, são os problemas que que defluem da potencial combinação entre iniciativas populares e referendos. Apesar de a Constituição de 1988 não ter previsto a realização de referendo para ratificação dos projetos submetidos ao Parlamento por meio de iniciativa popular, é importante examinar as possibilidades de combinação dos dois institutos, que, como aduzem Andreas Auer, Giorgio Malinverni e Michel Hottelier (2000, p. 35), se situam literalmente nos dois extremos do processo legislativo.

De fato, a utilização combinada dessas duas instituições, como ocorre na Suíça e nos Estados da Federação Norte-americana, amplia substancialmente as possibilidades da democracia semidireta. A aplicação do referendo para obtenção da palavra final do eleitorado a respeito de uma iniciativa popular retira do Legislativo a exclusividade de aprovação ou rejeição do projeto, atribuindo à iniciativa um potencial muito maior que de apenas provocar atuação do Parlamento.

De acordo com os resultados que deflagram, as iniciativas são classificadas em diretas e indiretas. As iniciativas diretas correspondem à apresentação de projetos de devem ser

\footnotetext{
${ }^{85} \mathrm{Na}$ Suíça, a iniciativa popular dos minaretes é um exemplo infame do uso de instrumentos de democracia direta visando a restringir direitos de minorias. Em 2009, foi aprovada, naquele país, uma emenda constitucional que baniu a construção de minaretes. A população muçulmana no país é minoritária, mas aumentou sensivelmente nas últimas décadas. Esse crescimento, combinado com a crescente hostilidade em relação ao Islã associada à guerra ao terrorismo parecem ter contribuído para a insatisfação e ressentimento relacionados à construção de novos minaretes, que eram vistos pelos proponentes da iniciativa como símbolos de poder e dominação. A despeito da oposição do governo suíço, a iniciativa venceu por $57,23 \%$ dos votos. A ausência de controle de constitucionalidade abstrato no sistema suíço impediu que a decisão fosse revertida. Esse episódio é emblemático de como é relevante, para proteção de direitos humanos de minorias, o alargamento do uso da iniciativa popular, que deve vir acompanhado do estabelecimento de restrições substantivas e a existência de controle judicial. Sobre o tema, veja-se: Claudia Josi (2016).
} 
imediatamente submetidos à aprovação popular por meio de referendo, sem transitar pelo parlamento (ballot initiative). No processo indireto, elas são submetidas ao legislativo, que pode trabalhar a proposta. Em alguns estados norte-americanos, o projeto de iniciativa popular é submetido às urnas se o legislativo a rejeita, promove alterações ou fica inerte. Em algumas localidades, legislativo pode submeter uma proposição alternativa que é submetida a referendo competindo com o projeto popular original. ${ }^{86}$

No Brasil, a Constituição não vinculou iniciativa e referendo, o que, inequivocamente, limita de forma substancial a força do instituto, já que os projetos populares estão sujeitos a todos os atrasos e protelações inerentes ao processo legislativo ordinário. A Lei 9.709/98 também não previu a combinação dos institutos. A aplicação do referendo e do plebiscito como ratificadores da iniciativa popular encontra ainda, na ordem constitucional brasileira, outro obstáculo. É que o artigo 49, XV da Carta de 1988 arrola entre as atribuições exclusivas do Congresso "autorizar referendo e convocar plebiscito", excluindo, assim, a possibilidade de que a lei regulamentadora estabelecesse a obrigatoriedade de referendo para ou plebiscito como etapa final do procedimento deflagrado por meio de iniciativa popular. Em face dessa disposição, Benevides (1996, p. 122) sustenta a possibilidade de a iniciativa popular ser utilizada apenas para realização de plebiscitos, já que a exclusividade Congresso nesse caso é apenas para convocação. Sustenta a autora que "pode haver iniciativa popular vinculante para a realização de plebiscitos - mas não para referendos".

Todavia, não há como estabelecer vinculação em nenhuma das hipóteses - seja de referendo, seja de plebiscito - tendo em vista que o primeiro dependerá de autorização do congresso e, o segundo, de que este proceda à convocação, o que também pode inviabilizar sua realização. Mas, como a Constituição de 1988 não estabeleceu qualquer restrição quanto às matérias que podem ser objeto de iniciativa popular, sempre haverá a possibilidade de o instituto ser empregado para que o Congresso delibere sobre a realização de referendo e de plebiscito sobre determinadas questões. Assim, é possível em nosso sistema a combinação dos institutos, mas sem vinculação, já que decisão final acerca da realização do referendo ou plebiscito caberá sempre ao Congresso Nacional.

Algumas cartas estaduais previram a possibilidade de o referendo ser realizado mediante proposta dos cidadãos. É o caso de São Paulo, cuja Constituição prevê em seu art. 24 a

${ }^{86}$ A Califórnia estabelece a iniciativa direta. Estados com fórmulas indiretas são, por exemplo, Maine e Massachusetts. Em Washington e Utah, são permitidos o método direto e o indireto. 
possibilidade de $1 \%$ do eleitorado requerer à Assembleia a realização de referendo sobre lei. A Constituição do Rio Grande do Sul previu também um mecanismo de vinculação entre o referendo e a iniciativa popular. De acordo com o artigo 68 daquela Carta, os projetos de iniciativa popular, quando rejeitados pela Assembleia Legislativa, serão submetidos a referendo popular se, no prazo de cento e vinte dias, dez por cento do eleitorado que tenha votado nas últimas eleições gerais do Estado o requerer. A questão que se coloca, quanto a este tópico, é se seria recomendável uma mudança no texto constitucional para que sejam ampliadas, no âmbito federal, as possibilidades de combinação entre o referendo e a iniciativa popular, estabelecendo-se hipóteses de vinculação obrigatória entre os institutos. Como sintetizou Arendt Lijphart (1989, p. 258), "o referendo por si só implica um passo muito modesto para a democracia, mas, combinado com a iniciativa, torna-se um passo gigantesco".

O problema é que, precisamente por isso, a combinação de iniciativas com referendos (iniciativa direta) amplia substancialmente os riscos e inconvenientes relacionados ao uso da democracia direta. Como já destacado, essa associação deve estar acompanhada de limites substantivos e da possibilidade de controle judicial posterior da adequação da medida.

\section{ENCERRAMENTO}

Apesar da limitada aplicação dos mecanismos de democracia semidireta na ordem constitucional brasileira, a representação tradicional tem apresentado inequívocos sinais de desgaste. Nos momentos de turbulência política, a abertura de canais institucionais de participação legislativa, mediados pelas garantias da autonomia individual do constitucionalismo liberal, pode cooperar para o atingimento de um equilíbrio entre as diversas forças políticas. A combinação entre fórmulas de exercício da autodeterminação popular e direitos fundamentais pode ser apta a conferir vitalidade à Constituição de 1988 sem comprometer sua permanência.

Na primeira parte desse artigo abordei as teorias participativas e elitistas de democracia. Na tradição democrática mais recente, ganharam força as teorias deliberativas da democracia. De acordo com essa corrente, que conquistou espaço na teoria política a partir da década de 1990, a democracia não corresponde apenas ao governo da maioria ou ao constitucionalismo, não se exaure em votos ou nos partidos e espaços estatais, mas pressupõe justificações discursivas e deliberação contínua ${ }^{87}$. De acordo com democratas deliberativos, a oportunidade dada às pessoas

\footnotetext{
87 Não há como enumerar todos os autores importantes dessa linha de pensamento, mas vale mencionar alguns como James Bohman, James Fishkin, Seyla Benhabib, Simone Chambers, Joshua Cohen, John Dryzek,
} 
de deliberar nas questões que afetam suas vidas é particularmente importante. Todos que são afetados pela teia normativa estatal têm o direito de participar da discussão sobre o a decisão a ser tomada. Além disso, muitos teóricos deliberativos não menosprezam o antagonismo e o conflito como elementos da democracia. Um aspecto que caracteriza a democracia deliberativa é a ideia de que os cidadãos e os agentes públicos devem fornecer razões e justificativas para embasar as leis que pretenderem adotar. Essas razões não podem ser puramente procedimentais (porque a maioria decidiu), nem puramente substantivas (porque é um direito humano) (GUTMANN, 2001, p. 137), mas precisam estar conectadas a um conjunto de princípios morais que todos possam razoavelmente aceitar. O processo de deliberação e justificação, que legitima as ações estatais, tem um valor autônomo, não meramente instrumental.

Na minha visão, o modelo teórico deliberativo não apenas é conciliável com as estruturas de participação direta, como explica de forma eficiente a sinergia entre autodeterminação política e direitos individuais que as constituições liberais que contemplam ferramentas de democracia semidireta pretendem promover. No caso das iniciativas populares, a associação com a democracia deliberativa parece particularmente apropriada, já que se trata de um canal que, se funcionar de forma adequada, pode encorajar a inserção de diferentes vozes no diálogo político. Em verdade, a iniciativa popular legislativa funciona como um elo entre participação e representação que conecta premissas da teoria da democracia participativa e da teoria deliberativa.

A participação direta dos indivíduos na formação das leis deve ser peça fundamental para o funcionamento de um sistema efetivamente democrático. Além de sua importância legitimadora, a participação na função legislativa assume um papel pedagógico que desemboca no desenvolvimento da cidadania. Aliada a freios relacionados à tutela dos direitos fundamentais e à proteção das minorias, ferramentas como a iniciativa popular podem cooperar para a construção de um espaço público ${ }^{88}$ político genuinamente deliberativo.

Jon Elster, Amy Gutmann, Jürgen Habermas, David Held e John Rawls.

${ }^{88}$ Habermas (1996, p. 361), que lida com a esfera pública como estrutura comunicacional conectada ao mundo da vida através da rede associativa da sociedade civil, descreve o espaço público político como esfera de ressonância de problemas que devem ser desenvolvidos no âmbito da esfera política porque não podem ser resolvidos em mais nenhum lugar. Dessa forma, a esfera pública é um sistema de aviso com sensores que, apesar de não especializados, são sensíveis aos apelos sociais. Para ele, na perspectiva da teoria democrática, a esfera pública deve amplificar a pressão dos problemas, o que significa não apenas detectálos e identificá-los, mas também convincentemente influenciar sua tematização, fornecendo possíveis soluções, e dramatizando-os de forma que sejam tomados e tratados por complexos parlamentares. 


\section{REFERÊNCIAS BIBLIOGRÁFICAS}

ACCIOLY, Wilson. Instituições de Direito Constitucional. 2. ed. Rio de Janeiro: Forense, 1981.

AGUIAR, Joaquim Castro. Competência e autonomia dos municípios na nova constituição. Rio de Janeiro: Forense, 1993.

ARENDT, Hannah. A Condição Humana. Forense: Rio de Janeiro, 1995.

ARNOLD, Felix; FREIER, Ronny. Signature Requirements and Citizen Initatives: Quasi-Experimental Evidence from Germany. DIW Discussion Papers, n. 1311, jul. 2013. Disponível em: <https://www.econstor.eu/bitstream/10419/78046/1/755980484.pdf>. Acesso em: 26 out. 2016.

AUER, Andreas; MALINVERNI, Giorgio; HOTTELIER, Michel. Droit constitutionnel suisse: les droits fundamentaux. Berne: Staempfli, 2000.

BARBER, Benjamin R. Strong democracy: participatory politics for a new age. California: University of California Press, 1984.

BENEVIDES, Maria Victoria. A cidadania ativa: referendo, plebiscito e iniciativa popular. São Paulo: Ed. Ática, 1996.

BOBBIO, Norberto. O Futuro da Democracia. Uma Defesa das Regras do Regras do Jogo, Rio de Janeiro: Paz e Terra, 1992a.

Direito e Estado no Pensamento de Emanuel Kant. Brasília: Edunb, 1992b.

O Conceito de Sociedade Civil. Rio de Janeiro: Graal, 1994.

Liberalismo e Democracia. São Paulo: Brasiliense, 1995a. $\overline{1995 b .}$

Estado, Governo, Sociedade. Para uma teoria geral da política. Rio de Janeiro: Paz e Terra, $\overline{1995 c}$.

Direita e esquerda: razões e significados de uma distinção política. São Paulo: Ed. Unesp, "Democracia". In: Dicionário de Política. Brasília: Editora UnB, 8ª ed., 1995d.

BONAVIDES, Paulo. Ciência Política. Rio de Janeiro: Forense, 1988.

História constitucional do Brasil. Rio de Janeiro: Paz e Terra, 1989.

Curso de direito constitucional. São Paulo: Malheiros, 1994.

BURDEAU, Georges. La démocratie. Neuchâtel: Editions de la Baconniére, 1956.

CAETANO, Marcelo. Direito constitucional. v. 1. Forense: Rio de Janeiro, 1987.

CAMPILONGO, Celso. "Democracia e legitimidade: representação política e paradigma dogmático". Revista de Informação Legislativa, a. 22. n. 86, abr-jun 1985, pp. 29-40

CANOTILHO, José Joaquim Gomes. Direito constitucional e teoria da constituição. Coimbra: Almedina, 1998. 
CASSIRER, Ernst. "A questão de Jean-Jacques Rousseau". O Pensamento Político Clássico. São Paulo, 1992.

CASTRO, Carlos Roberto de Siqueira. O Congresso e as Delegações Legislativas. Rio de Janeiro: Ed. Forense, 1996.

CARDOSO, Ciro Flamarion. A cidade-estado antiga. São Paulo: Ática. 1993.

CARDOSO, Rodrigo Mendes. A iniciativa popular legislativa da Assembleia Nacional Constituinte ao regime da Constituição de 1988: um balanço. Dissertação (Mestrado em Direito) - Pontifícia Universidade Católica do Rio de Janeiro (PUC-RIO), Rio de Janeiro, 2010.

CHEMERINSKY, Erwin. Challengig Direct Democracy. Mich St. L. Rev., n. 293, 2007, p. 293-306.

CLARK, Sherman J. A Populist Critique of Direct Democracy. Harvard Law Review, v. 112, n. 2, dec. 1998, p. 434-482.

CLAVREUL, Collete. "Sieyés et la genése de la représentation moderne". Droits - Révue Française de Théorie Juridique, n. 6, outubro 1987, pp. $45-56$.

CLÉVE, Clémerson Merlin. Atividade legislativa do poder executivo no estado contemporâneo e na constituição de 1988. São Paulo: Revista dos Tribunais, 1993.

COMPARATO, Fábio Konder. Muda Brasil: uma Constituição para o desenvolvimento democrático. São Paulo, Brasiliense, 1986.

“Emenda e Revisão na Constituição de 1988". Revista de Direito Público, n. 93, jan-mar 1990, pp. $125-128$.

"A Nova Cidadania". Revista Lua Nova. São Paulo, n. 33, p. 85-106, 1994.

CONNOLLY, William. The Terms of Political Discourse. 3. ed. Oxford: Blackwell, 1993.

CONSTANT, Benjamim. Da liberdade dos antigos comparada à dos modernos. In: Filosofia Política 3, Porto Alegre: LP\&M, 1985.

Princípios políticos constitucionais. Rio de Janeiro: Liber Juris, 1989.

COULANGES, Fustel de. A cidade antiga. São Paulo: Martins Fontes, 1998.

DAHL, Robert. Um Prefácio à Teoria Democrática. Rio de Janeiro: Jorge Zahar Editor, 1992.

Poliarquia: participação e oposição. São Paulo: Edusp, 1997.

DALLARI, Dalmo de Abreu. Elementos de Teoria Geral do Estado. São Paulo: Saraiva, 1982.

"Formas de participação política". Revista da Procuradoria Geral do Estado de São Paulo, número especial: Propostas para a constituinte, n. 24, dez. 1985, pp. 135-147.

"Mecanismos de participação popular e suas conquistas". Problemas e reformas: subsídios para o debate constituinte. São Paulo: OAB-SP, 1988.

"A participação popular e suas conquistas". In: WHITAKER, F. et. al. (Orgs.). Cidadão Constituinte: a saga das emendas populares. São Paulo: Paz e Terra, 1989.

Muda Brasil: uma Constituição para o desenvolvimento democrático. São Paulo: Brasiliense, 
1986.

DUHAMEL, Olivier. Les démocraties. Paris: Éditions du Seuil, 1993.

FERNANDES, Florestan. O uso da iniciativa popular. Folha de São Paulo, São Paulo. 03 abr. 1987. Disponível

em: <http://www2.senado.leg.br/bdsf/bitstream/handle/id/115293/1987_01\%20a\%2007\%20de\%20Ab ril_050.pdf?sequence=1>. Acesso em: 22 out. 2016.

FERRARI FILHO, Sérgio Antônio. Constituição Estadual e Federação. Rio de Janeiro: Lumen Juris, 2008.

FERRAZ JUNIOR, Tercio Sampaio. A convocação da constituinte como problema de controle constitucional. In: O Direito, 1988, p. 7 e ss. apud MIRANDA. Jorge. Manual de direito constitucional. Tomo II. Coimbra: Coimbra Editora, 2013.

FERREIRA, Luís Pinto. Proposta de uma Constituição para a República Federativa do Brasil. Recife: Editora da Faculdade de Direito de Pernambuco, 1985

FERREIRA FILHO, Manoel Gonçalves. Do processo legislativo, São Paulo: Saraiva, 1995.

FINLEY, Moses I. Politics in the ancient world. Cambridge: Cambridge University Press, 1983.

FREEDEN, Michael. Ideologies and Political Theory: a conceptual approach. Oxford: Oxford University Press, 1998.

GALLIE, W. B. Essentially contested concepts. Proceedings of the Aristotelian Society, New Series, v. 56, 2955-1956, p. 167-198.

GARCÍA-PELAYO, Manuel. Derecho constitucional comparado. Madrid: Alianza Editorial, 1993.

GAUDEMET, Paul. "Choses vues: les landsgemeinde, survivance de la democratie directe". In Pouvoirs, Révue Française d'Études Constitutionnelles et Politiques, n. 51, 1989.

GOMES, Helton Simões. Internet chega pela $1^{\text {a }}$ vez a mais de 50\% das casas no Brasil, mostra IBGE. G1, São Paulo, 06 abr. 2016.2 Disponível em: <http://g1.globo.com/tecnologia/noticia/2016/04/internet-chega-pela-1-vez-mais-de-50-dascasas-no-brasil-mostra-ibge.html>. Acesso em: 26 out. 2016.

GUTMANN, Amy. Democracy, In: GOODIN, Robert E.; PETTIT, Philip; POGGE, Thomas. (Eds.). A Companion to Contemporary Political Philosophy, Blackwell Publishing, 2007, p. 521-531. "Deliberative democracy". In: BARRY, Paul Clarke; FOWERAKER, Joe (Eds.). Encyclopedia of democratic thought. New York: Routledge, 2001.

HABERMAS, Jürgen. Between Facts and Norms: Contributions to a Discourse Theory of Law and Democracy. Massachusetts: MIT Press, 1996.

HAURIOU, André. Droit constitutionnel et instituitions politiques. Paris: Montchrestien, 1972. 
HELD, David. Models of Demoracy. Standford: Standford University Press, 1987.

HOBSBAWN, Eric J. A Era das Revoluções: Europa 1789-1848, 9. ed., São Paulo: Paz e Terra, 1996.

HORTA, Raul Machado. Estudos de direito constitucional. Belo Horizonte: Del Rey, 1995.

INITIATIVE \& REFERENDUM INSTITUTE. Comparison of Statewide Initiative Processes. Disponível

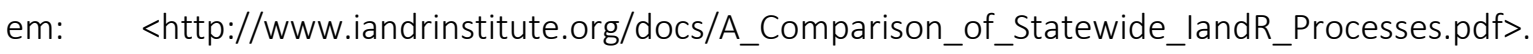
Acesso em: 25 out. 2016.

JELLINEK, Georg. Reforma y mutacion de la constitucion. Madrid: Centro de Estudios Constitucionales, 1991.

JOSI, Claudia. Direct Democracy vs Fundamental Rights? A Comparative Analysis of the Mechanisms that Limit the 'Will of the People' in Switzerland and California. In: CONTIADES, Xenophon; FOTIADOU, Alkmene (Eds.). Participatory constitucional change: The people as amenders of the constitution. New York: Routledge, 2016.

KENNETH, Miller P. Direct democracy and courts. Cambridge: Cambridge University Press, 2009.

KRYMEN, Jaques. "La représentation politique dans I'ancienne France". Droits - Révue Française de Théorie Juridique, n. 6, outubro 1987, pp. 31-44.

LAFER, Celso. A Reconstrução dos Direitos Humanos - Um Diálogo com o Pensamento de Hannah Arendt. São Paulo, Cia. das Letras, 1991.

LIJPHART, Arend. As democracias contemporâneas. Lisboa: Gradiva, 1989.

LOEWENSTEIN, Karl. Teoria de la constituición. 2. ed. Barcelona: Ariel, 1976.

LUQUE, Luis Aguiar de. Democracia Directa y Estado Constitucional. Madrid: Editorial Revista de Derecho Privado, 1977.

MACPHERSON, C. B. A democracia liberal - origens e evolução. Rio de Janeiro, Zahar, 1978.

The life and times of liberal democracy. Oxford: Oxford University Press, 1977.

MALBERG, R. Carré de. Teoria General del Estado. México, D.F.: Fondo de Cultura Econômica, 1948. Contribuition à la theorie générale de l'État - spécialment d'aprés les donnés fournies par le droit constitionnel français. Paris: Recueil Sirey, 1922, T. I.

MELLO, Humberto Laport de. A democracia participativa e sua institucionalização pela ordem constitucional de 1988: propostas de desenvolvimento e parâmetros de aplicação do plebiscito, do referendo e da iniciativa popular. Dissertação (Mestrado em Direito) - Universidade do Estado do Rio de Janeiro, Rio de Janeiro, 2013.

MICHELS, Robert. Sociologia dos Partidos Políticos. Brasília: Editora UnB, 1982.

MIRANDA, Jorge. Funções, Órgãos e Actos de Estado. Lisboa: Faculdade de Direito de Lisboa, 1990.

Revista de Direito da Cidade, vol. 08, no 4. ISSN 2317-7721 pp. 1707- 17561754 
MOISÉS, José Álvaro. Cidadania e participação: ensaio sobre o plebiscito, o referendo e a iniciativa popular. São Paulo: Marco Zero, 1990.

MONTESQUIEU. O espírito das leis. São Paulo: Martins Fontes, 1996.

MORTATI, Constantino. Instituizioni di diritto pubblico. Padova: CEDAM, 1967.

MOSCA, Gaetano. The Ruling Class. New York: McGraw-Hill, 1939.

MOSSÉ, Claude. Histoire d’une démocratie: Athénes. Paris: Editions du Seuil, 1971.

NETO, Diogo de Figueiredo Moreira. Direito da participação política. Rio de Janeiro: Renovar, 1992.

PATEMAN, Carole. Participação e Teoria Democrática, Rio de Janeiro: Paz e Terra, 1992.

Participation and Democratic Theory. Cambridge: Cambridge University Press, 1970.

PARETO, Vilfredo. The Mind and Society: A Treatise on General Sociology. New York: Harcourt, Brace, 1935.

PIRES, Thiago Magalhães. As competências legislativas na constituição de 1988: uma releitura de sua interpretação e da solução de seus conflitos à luz do Direito Constitucional contemporâneo. Belo Horizonte: Fórum, 2015.

RIVERO, Jean. Curso de Direito Administrativo Comparado, São Paulo: Revista dos Tribunais, 1995.

RODRIGUES, Luís Barbosa. O referendo português a nível nacional. Coimbra: Coimbra Editora, 1994.

ROSENFELD, Michel; SAJÓ, András (Eds.). The Oxford Handbook of Comparative Law. Oxford: Oxford University Press, 2012.

ROUSSEAU, Jean-Jacques. O Contrato Social. Col. Os Pensadores. São Paulo: Abril, 1978.

O Contrato Social. São Paulo: Martins Fontes, 1993.

Discurso sobre a Desigualdade entre os Homens. Col. Os Pensadores, São Paulo, Abril, 1978.

RUFFIA, Paolo Biscaretti di. Direito Constitucional. São Paulo: Revista dos Tribunais, 1984. 1996. Introducción al derecho constitucional comparado. México: Fondo de Cultura Econômica,

SAMPAIO, Nelson de Sousa. O poder de reforma constitucional. Belo Horizonte: Nova Alvorada, 1995.

SANTOS, Boaventura de Souza. Introdução a uma Ciência Pós-moderna. Lisboa: Edições Afrontamento, 1989.

Pela mão de Alice. São Paulo: Cortez. 1995.

SARTORI, Giovanni. A teoria da democracia revisitada. vol. I. São Paulo: Ática, 1994. 
SCHUMPETER, Joseph. Capitalismo, socialismo e democracia. Rio de Janeiro: Zahar Editores, 1984.

SILVA, José Afonso da. Curso de direito constitucional positivo. 9. ed. rev. e ampl. São Paulo: Malheiros, 1992.

Curso de direito constitucional positivo. 26. ed., rev. e atual. São Paulo: Malheiros, 2006a.

Princípios do processo de formação das leis no direito constitucional. São Paulo: Revista dos Tribunais, 1964.

Processo constitucional de formação das leis. 2. ed. São Paulo: Malheiros, 2006b.

Proposta de uma Constituição para a República Federativa do Brasil. Recife: Editora da Faculdade de Direito de Pernambuco, 1985.

Plano para uma constituição federal do brasil. Mimeo.

SGARBI, Adrian. O referendo. Rio de Janeiro: Renovar, 1999.

TOUCHARD, Jean. História das Idéias Políticas. Lisboa, Publicações Europa-América, 1970, vol. 4.

VERDU, Pablo Lucas. Curso de derecho politico. vol. I, Madrid: Editorial Tecnos, 1972.

VIADEL, Antonio Colomer. Introducción al constitucionalismo iberoamericano. Ediciones de cultura hispânica: Madrid, 1990.

WHITAKER, Francisco. Iniciativa popular de leis: limites e alternativas. In BENEVIDES, Maria Victoria; VANNUCHI, Paulo; KERCHE, Fábio (Orgs.). Reforma política e cidadania. São Paulo: Editora Fundação Perseu Abramo, 2003.

Trabalho enviado em 28 de outubro de 2016.

Aceito em 13 de novembro de 2016. 